\title{
C-H Oxidative Addition of Bisimidazolium Salts to Iridium and Rhodium Complexes, and N-Heterocyclic Carbene Generation. A Combined Experimental and Theoretical Study
}

\author{
Mónica Viciano,$^{\dagger}$ Macarena Poyatos, ${ }^{\dagger}$ Mercedes Sanaú, ${ }^{\ddagger}$ Eduardo Peris,,${ }^{* \dagger}$ Andrea Rossin,${ }^{\S}$ \\ Gregori Ujaque, ${ }^{\S}$ and Agustí Lledós*, ${ }^{*}$ \\ Departamento de Química Inorgánica y Orgánica, Universitat Jaume I, Avenida Vicente Sos Baynat s/n, \\ 12080 Castellón, Spain, Departamento de Química Inorgánica, Universitat de Valencia, \\ Avenida Dr. Moliner s/n, 46100-Burjassot (Valencia), Spain, and Departamento de Química, \\ Universitat Autònoma de Barcelona, Edifici Cn., 08193 Bellaterra (Barcelona), Spain
}

Received November 22, 2005

\begin{abstract}
A series of bis-N-heterocyclic carbenes of rhodium and iridium have been obtained and characterized. The formation of the $\mathrm{M}-\mathrm{C}$ bond has been studied according to experimental and theoretical data, showing that two different mechanisms are operative for the first (single proton deprotonation of the bisimidazolium salt, or oxidative addition followed by deprotonation of the metal hydride) and second (oxidative addition of the second bisimidazolium $\mathrm{C}-\mathrm{H}$ bond, yielding a NHC-Ir ${ }^{\mathrm{III}}-\mathrm{H}$ species) metalation processes. In the case of complexes with long linkers between the imidazolium rings, reductive elimination of $\mathrm{HCl}$ affords bisimidazolylidene complexes of $\mathrm{Ir}^{\mathrm{I}}$. According to the theoretical studies we concluded that thermodynamic parameters would determine the formation of the NHC-Ir ${ }^{\mathrm{III}}-\mathrm{H}$ species, while $\mathrm{Ir}^{\mathrm{I}}-\mathrm{NHC}$ species would be kinetically favored in the case of complexes with long linkers between the azole rings. The crystal structures of a series of Ir-bis(NHC) complexes are described.
\end{abstract}

\section{Introduction}

$\mathrm{N}$-Heterocyclic carbenes (NHCs) derived from imidazolium salts have provided an extraordinary, versatile source of ligands in the preparation of effective homogeneous catalysts. ${ }^{1,2}$ Despite the relative recent use of NHCs in the design of catalysts, the area has developed so fast that we now have access to a large library of ligands with different topologies and electronic properties.

$\mathrm{We}^{2-7}$ and others ${ }^{8,9}$ have studied the effect of chelate $\mathrm{N}$-heterocyclic carbenes as a way to obtain highly stable catalysts capable of tolerating harsher reaction conditions than traditional phosphine catalysts. Among the ligands that we have used, those with pincer ${ }^{3,10}$ and tripodal ${ }^{5}$ coordination provided complexes that combine an extraordinary high stability with excellent catalytic activity. Bidentate-chelate carbenes also

\footnotetext{
* To whom correspondence should be addressed. E-mail: eperis@ qio.uji.es agusti@klingon.uab.es.

Universitat Jaume I.

$\doteqdot$ Universitat de Valencia.

$\S$ Universitat Autònoma de Barcelona.

(1) (a) Bourissou, D.; Guerret, O.; Gabbai, F. P.; Bertrand, G. Chem. Rev. 2000, 100, 39. (b) Cavell, K. J.; McGuinness, D. S. Coord. Chem. Rev. 2004, 248, 671. (c) Peris, E.; Crabtree, R. H. C. R. Chimie 2003, 6, 33. (d) Herrmann, W. A. Angew. Chem., Int. Ed. 2002, 41, 1291. (e) Arduengo, A. J. Acc. Chem. Res. 1999, 32, 913. (f) Crudden, C. M.; Allen, D. P. Coord. Chem. Rev. 2004, 248, 2247.

(2) Peris, E.; Crabtree, R. H. Coord. Chem. Rev. 2004, 248, 2239.

(3) (a) Peris, E.; Loch, J. A.; Mata, J.; Crabtree, R. H. Chem. Commun. 2001, 201. (b) Poyatos, M.; Mata, J. A.; Falomir, E.; Crabtree, R. H.; Peris, E. Organometallics 2003, 22, 1110. (c) Poyatos, M.; Mas-Marza, E.; Mata,

J. A.; Sanau, M.; Peris, E. Eur. J. Inorg. Chem. 2003, 1215.

(4) Mas-Marza, E.; Segarra, A. M.; Claver, C.; Peris, E.; Fernandez, E. Tetrahedron Lett. 2003, 44, 6595.

(5) (a) Mas-Marza, E.; Poyatos, M.; Sanau, M.; Peris, E. Organometallics 2004, 23, 323. (b) Mas-Marza, E.; Poyatos, M.; Sanau, M.; Peris, E. Inorg. Chem. 2004, 43, 2213.

(6) Poyatos, M.; Sanau, M.; Peris, E. Inorg. Chem. 2003, 42, 2572.

(7) Poyatos, M.; Mas-Marza, E.; Sanau, M.; Peris, E. Inorg. Chem. 2004
} $43,1793$. provided an excellent way to study the effects of ligand anisotropy on the reactivity of the complexes formed. ${ }^{6}$ However, in most of the cases that we studied, the traditional metalation procedure involving deprotonation of the imidazolium salt with a strong base is no longer valid due to the presence of linkers with acidic groups sensitive to strong bases, so our preparation methods are limited to the use of weak bases such as NaOAc or $\mathrm{NEt}_{3}$.

In a recent study, we described that bis(imidazolium) salts having $\left(\mathrm{CH}_{2}\right)_{n}$ chains of different lengths $(n=1-4)$ linking the diazole rings showed different reactivity patterns on metalating to $[(\mathrm{COD}) \mathrm{RhCl}]_{2} \cdot{ }^{11}$ Long linkers $(n=3,4)$ favored the formation of square planar $\mathrm{Rh}(\mathrm{I})$ complexes, while short linkers $(n=1,2)$ produced pseudooctahedral $\mathrm{Rh}(\mathrm{III})$ species. We ascribed the origin of this effect to the restricted rotation of the diazole rings and the different preferred orientations of these rings as $n$ changes. A question that remained unsolved was the oxidation of the $\mathrm{Rh}(\mathrm{I})$ complexes to $\mathrm{Rh}(\mathrm{III})$, although we had previously proposed a mechanism based on the role played by the counteranion of the bis(imidazolium) salt. ${ }^{6}$ More recently, we observed the $\mathrm{C} 2-\mathrm{H}$ oxidative addition of a ferrocenylbis(imidazolium) precursor yielding a stable (biscarbene) $\mathrm{Ir}^{\mathrm{III}} \mathrm{H}$ complex

(8) (a) Fehlhammer, W. P.; Bliss, T.; Kernbach, U.; Brudgam, I. J. Organomet. Chem. 1995, 490, 149. (b) Crabtree, R. H. Pure Appl. Chem. 2003, 75, 435. (c) Danopoulos, A. A.; Tulloch, A. A. D.; Winston, S.; Eastham, G.; Hursthouse, M. B. Dalton Trans. 2003, 1009. (d) Panda, B. K.; Sengupta, S.; Chakravorty, A. Eur. J. Inorg. Chem. 2004, 178. (e) Herrmann, W. A.; Schwarz, J.; Gardiner, M. G. Organometallics 1999, 18 , 4082. (f) Magill, A. M.; McGuinness, D. S.; Cavell, K. J.; Britovsek, G. J. P.; Gibson, V. C.; White, A. J. P.; Williams, D. J.; White, A. H.; Skelton, B. W. J. Organomet. Chem. 2001, 617, 546.

(9) Albrecht, M.; Miecznikowski, J. R.; Samuel, A.; Faller, J. W.; Crabtree, R. H. Organometallics 2002, 21, 3596.

(10) Loch, J. A.; Albrecht, M.; Peris, E.; Mata, J.; Faller, J. W.; Crabtree, R. H. Organometallics 2002, 21, 700.

(11) Mata, J. A.; Chianese, A. R.; Miecznikowski, J. R.; Poyatos, M.; Peris, E.; Faller, J. W.; Crabtree, R. H. Organometallics 2004, 23, 1253. 
Scheme 1

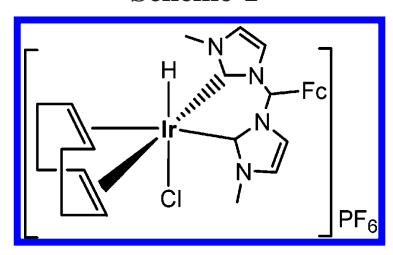

(Scheme 1). ${ }^{12}$ In fact, despite finding the $\mathrm{C} 2-\mathrm{H}$ oxidative addition process to account only for our ferrocenylbis(imidazolium) precursor, we believe that it could be of more general application and, hence, could explain the oxidation of some other metals upon coordinating to NHC ligands.

Oxidative addition via activation of the $\mathrm{C} 2-\mathrm{H}$ of an imidazolium cation has been elegantly proved by Cavell and co-workers to low-valent electron-rich coordinatively unsaturated group 10 metal complexes. ${ }^{13} \mathrm{~A}$ few months later, the first catalytic derivations of the process were already pointed out by the same research team, ${ }^{14}$ and in a different study they theoretically studied the oxidative addition of azolium salts to a model Rh(I) complex. ${ }^{15}$

Even though $\mathrm{C} 2-\mathrm{H}$ oxidative addition of imidazolium salts has proved possible at certain metal complexes under special circumstances, we are far from considering it a method of general application to the synthesis of NHC complexes. For example, in our recent work describing the oxidative addition of a ferrocenylbis(imidazolium) salt to an $\operatorname{Ir}(\mathrm{I})$ complex, ${ }^{12}$ we ascribed the stability of the NHC-Ir-H compound to the presence of the ferrocenyl fragment, which might be sterically hindering the hydride and so preventing the complex from reductively eliminating $\mathrm{HCl}$ or the imidazolium cation. The presence of the ferrocenyl unit seemed determinant in the detection of the hydride-metal-carbene. Although more detailed studies are needed, we believe that our observations may modify current mechanistic concepts in $\mathrm{NHC}-\mathrm{M}$ bond formation, especially when a weak base is used to promote the metalation.

In a continuation of our research, we thought that we should try to answer some of the questions regarding the formation of NHC-metalated species of $\mathrm{Rh}$ and $\mathrm{Ir}$, to find if a general metalation procedure can be established. Some of these questions are, for example, is the oxidation of the metal always a consequence of the oxidative addition of the imidazolium salt precursor? Do Rh and Ir follow similar NHC-metalation patterns? In the cases where the chelating ligand provides square planar M(I) complexes, should we discard the possibility that the oxidative addition has occurred? Are the different reactivity patterns in the metalation of bis(imidazolium) salts with different linker lengths $\left[-\left(\mathrm{CH}_{2}\right)_{n}-; n=1-4\right]$ due to kinetically or thermodynamically controlled mechanisms? In this paper we try to give answers to these questions by experimentally studying the metalation of a series of bis(imidazolium) salts to [(COD)$\mathrm{MCl}]_{2}(\mathrm{M}=\mathrm{Rh}$ and $\mathrm{Ir})$ and theoretically analyzing the mechanism of the N-heterocyclic carbene generation. A detailed comparison of the reactivity of the two metals with different

(12) Viciano, M.; Mas-Marza, E.; Poyatos, M.; Sanau, M.; Crabtree, R. H.; Peris, E. Angew. Chem., Int. Ed. 2005, 44, 444.

(13) (a) Duin, M. A.; Clement, N. D.; Cavell, K. J.; Elsevier, C. J. Chem. Commun. 2003, 400. (b) Clement, N. D.; Cavell, K. J.; Jones, C.; Elsevier, C. J. Angew. Chem., Int. Ed. 2004, 43, 1277. (c) McGuinness, D. S.; Cavell, K. J.; Yates, B. F.; Skelton, B. W.; White, A. H. J. Am. Chem. Soc. 2001, 123, 8317. (d) McGuinness, D. S.; Cavell, K. J.; Yates, B. F. Chem. Commun. 2001, 355.

(14) Clement, N. D.; Cavell, K. J. Angew. Chem., Int. Ed. 2004, 43, 3845 .

(15) Hawkes, K. J.; McGuinness, D. S.; Cavell, K. J.; Yates, B. F. Dalton Trans. 2004, 2505. bis(imidazolium) precursors is established, and a series of NHC$\mathrm{Ir}^{\mathrm{III}}$-H complexes have been obtained. The orientation of the azole rings in the coordination sphere of the metal is determining whether the $\mathrm{M}(\mathrm{I})$ or $\mathrm{M}(\mathrm{III})$ is formed, although in a different manner from the one we proposed in our previously published work. ${ }^{11}$ The molecular structures of some of the complexes that we have obtained are described, providing a solid support to our conclusions.

\section{Results}

Reaction of Methylenebis( $N$-methylimidazolium) Hexafluorophosphate $(n=1)$ with $[(C O D) M C l]_{2}(M=I r, R h)$. For the preparation of the NHC complexes we decided to use the $\mathrm{PF}_{6}$ salts of the bis(imidazolium) precursors instead of the halide salts. We have seen that the presence of halides in the reaction medium may sometimes lead to decomposition products, ${ }^{11}$ while $\mathrm{PF}_{6}$ salts give more stable compounds. The reactions between $[(\mathrm{COD}) \mathrm{MCl}]_{2}(\mathrm{M}=\mathrm{Ir}$ and $\mathrm{Rh})$ and methylenebis $(N$-methylimidazolium) hexafluorophosphate are performed by dissolving an equimolar mixture of the two compounds in $\mathrm{CH}_{3} \mathrm{CN}$ with $\mathrm{NEt}_{3}$ at room temperature. The reaction proceeds at different reaction rates for the Ir and $\mathrm{Rh}$ cases. For the Ir case, the reaction proceeds via a monometalated intermediate (1Ir), which rapidly evolves $(1 \mathrm{~h})$ to its oxidative addition product, $\mathbf{2} \mathbf{I r}$, an (NHC)$\mathrm{Ir}(\mathrm{III})$-hydride, in which the hydride would be trans to the $\mathrm{Cl}$ ligand. 2Ir is similar to our previously reported hydride (Scheme 1) with a ferrocenyl-biscarbene ligand. ${ }^{12}$ The intermediate $\mathbf{1 I r}$ could not be isolated from the reaction medium because it rapidly evolved to $\mathbf{2 I r}$. The NHC-Ir-H compound, $2 \mathbf{I r}$, can be obtained by washing the corresponding reaction mixture with $\mathrm{CH}_{2} \mathrm{Cl}_{2}$. The ${ }^{1} \mathrm{HNMR}$ spectrum of $\mathbf{1 I r}$ reveals that the 2-fold symmetry of the ligand is lost upon coordination. The signal of the proton in the $2^{\prime}$-position of the unbound imidazolium functionality appears at $\delta=9.32$. The signals of the protons of the bound imidazolylidene ring appear at higher field than those of the unbound ring, thus indicating its coordination. The ${ }^{13} \mathrm{C}$ NMR spectrum shows the signal of the metalated carbon at $\delta$ $=$ 181.9. Similar NMR patterns have been observed for related ligands in the monometalated form. ${ }^{7,12}$ For $2 \mathbf{I r}$, the signal of the hydride appears as a singlet at $\delta=-15.6$. The equivalency of the signals due to the imidazolylidene rings is consistent with the trans configuration of the compound. The ${ }^{13} \mathrm{C} N M R$ spectrum shows a signal at $\delta=146.8$, in the region where other metalated NHC complexes of Ir(III) appear, thus confirming that the metalation has occurred.

For the $\mathrm{Rh}$ case, the monometalated intermediate $\mathbf{1} \mathbf{R h}$ is formed a few minutes after the addition of $\mathrm{NEt}_{3}$. 1Rh slowly evolves to the $\mathrm{Rh}(\mathrm{III})$ hydride species, $\mathbf{2} \mathbf{R h}$, and the reaction is complete in 4 days (Scheme 2), although we were unable to isolate and hence fully characterize this new $\mathrm{Rh}(\mathrm{III})$ species. The intermediate 1Rh can be purified by column chromatography on silica gel. $\mathbf{1 R h}$ was unambiguously characterized by NMR spectroscopy and mass spectroscopic analysis, and $\mathbf{2} \mathbf{R h}$ could be characterized only by ${ }^{1} \mathrm{H}$ NMR spectroscopy. The ${ }^{1} \mathrm{H}$ NMR spectrum of $\mathbf{1 R h}$ has a pattern similar to that shown for 1Ir. A downfield signal at $\delta=9.5$ is attributed to the proton in the $2^{\prime}$-position of one imidazolium ring, thus revealing that one of the rings remains unbound. The ${ }^{13} \mathrm{C}$ NMR spectrum shows a doublet at $\delta=185.8\left({ }^{1} J_{\mathrm{Rh}-\mathrm{C}}=51.4 \mathrm{~Hz}\right)$, confirming that metalation has occurred. The more significant feature of the ${ }^{1} \mathrm{H}$ NMR spectrum of $\mathbf{2} \mathbf{R h}$ is the appearance of a doublet due to the resonance of the hydride at $\delta=-16.7\left({ }^{1} J_{\mathrm{Rh}-\mathrm{H}}=25.5\right.$ $\mathrm{Hz}$ ). The equivalency of imidazolylidene rings confirms that the 2-fold symmetry is maintained in the compound. Although 
Scheme 2

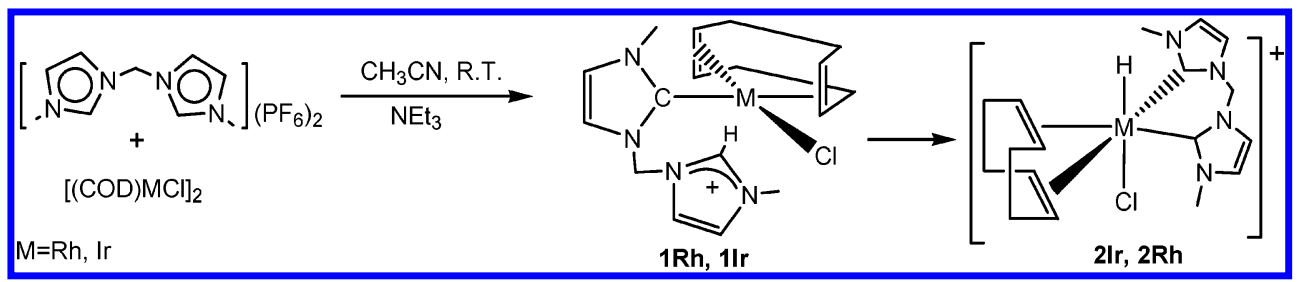

we could not isolate this complex to perform a complete characterization, we believe that the spectroscopic similarities to 2Ir give strong support to our structure assignment. This compound represents the first example of a (NHC)-Rh-hydride complex obtained by oxidative addition of an imidazolium salt, although theoretical approaches have already proposed that this type of compound may be produced by this process. ${ }^{15}$

Crystal Structure of 2Ir. The molecular structure of 2Ir was confirmed by single-crystal X-ray diffraction analysis. Figure 1 shows the ORTEP diagram and the more relevant lengths and angles. The Ir adopts a distorted octahedral geometry with a biscarbene bite angle $\mathrm{C}-\mathrm{Ir}-\mathrm{C}$ of $84.6^{\circ}$. The $\mathrm{Ir}-\mathrm{C}$ bond lengths of 2.048 and $2.056 \AA$ lie in the range of previously reported Ir $-\mathrm{C}$ bond lengths. ${ }^{12,16,17}$ The $\mathrm{Ir}-\mathrm{H}$ bond length is 1.64(9) $\AA$, with a relative angle to the trans $\mathrm{Cl}$ atom of $161^{\circ}$. The average angle of the imidazolylidene rings and the coordination plane of the molecule is $39.3^{\circ}$.

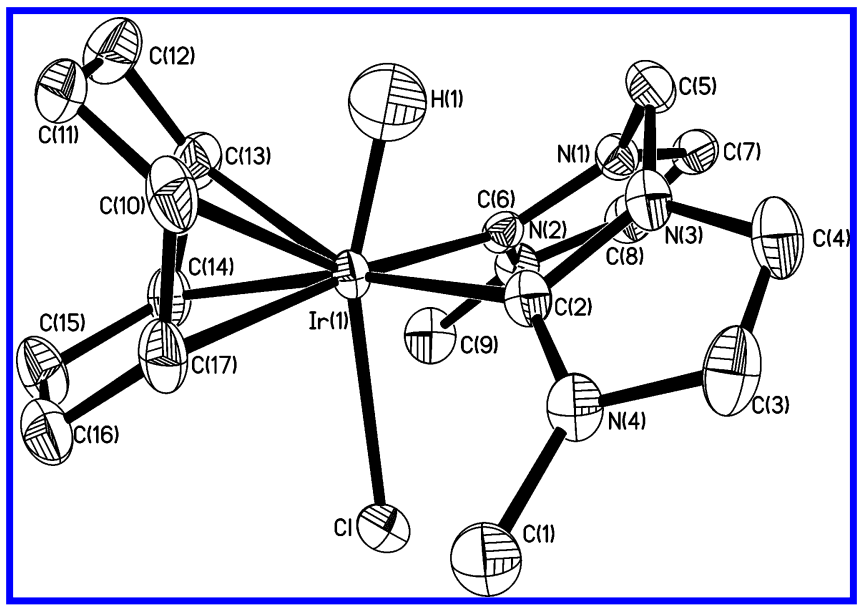

Figure 1. ORTEP diagram of 2Ir. Hydrogen atoms and counterion $\left(\mathrm{PF}_{6}{ }^{-}\right)$are omitted for clarity. Selected bond $(\AA)$ lengths and angles (deg): $\quad \operatorname{Ir}(1)-\mathrm{H}(1) \quad 1.64(9), \quad \operatorname{Ir}(1)-\mathrm{C}(2) \quad 2.048(5), \quad \operatorname{Ir}(1)-\mathrm{C}(6)$ 2.056(5), $\operatorname{Ir}(1)-\mathrm{Cl} 2.4942(14) ; \mathrm{H}(1)-\operatorname{Ir}(1)-\mathrm{Cl} 161(3), \mathrm{C}(2)-\mathrm{Ir}-$ (1) $-\mathrm{C}(6) 84.64(19)$.

Direct Metalation Reaction between Longer Linked Bis(imidazolium) Hexafluorophostate Salts and $[(\mathrm{COD}) \mathrm{IrCl}]_{2}$. The direct metalation reactions between bis(imidazolium) salts with different linker lengths $\left[-\left(\mathrm{CH}_{2}\right)_{n}-; n=2-4\right]$ are performed in a manner similar to that described for [(COD)-
$\operatorname{IrCl}]_{2}$ and methylenebis( $N$-methylimidazolium) hexafluorophosphate. The azolium salt and $[(\mathrm{COD}) \mathrm{IrCl}]_{2}$ (Ir:bis(imidazolium) salt, 1:1) were dissolved in $\mathrm{CH}_{3} \mathrm{CN}$ in the presence of $\mathrm{NEt}_{3}$ (or $\mathrm{Cs}_{2} \mathrm{CO}_{3}$ ) at $60^{\circ} \mathrm{C}$. The formation of the monometalated species $\mathbf{3 a}-\mathbf{5 a}$ was complete after $4 \mathrm{~h}$, according to the reaction scheme depicted in Scheme 3. Longer reaction times (12 h) afforded the formation of the doubly metalated species $\mathbf{6 a}-\mathbf{8 a}$. The monometalated species were precipitated as pale orange compounds in a mixture of $\mathrm{CH}_{2} \mathrm{Cl}_{2} / \mathrm{Et}_{2} \mathrm{O}$. The isolation of the doubly metalated compounds required prior purification by column chromatography.

Compounds $\mathbf{6 a}-\mathbf{8 a}$ can also be obtained by transmetalation of the carbenes from the corresponding silver carbene derivatives in $\mathrm{CH}_{3} \mathrm{OH}$. Transmetalation from silver-NHC complexes has proved to be an effective procedure to obtain NHC metal complexes. ${ }^{18}$ Although the silver-NHC complexes can be isolated as white solids, we decided to use them in situ, after filtering through Celite in order to eliminate the generated silver halides and unreacted silver oxide. Then, addition of the corresponding amount of $[(\mathrm{COD}) \mathrm{IrCl}]_{2}$ and reaction at room temperature for $3 \mathrm{~h}$ provided us the best results (Scheme 4), although with extremely low yields (ca. 5-10\%), probably due to the low solubility of their silver-NHC complexes, which may have been lost during the filtration. The $n$-butyl analogues $\mathbf{6 b}-$ $\mathbf{8 b}$ were obtained in high yield $(60-70 \%)$ after purification of the reaction products by column chromatography.

All the complexes were satisfactorily characterized by NMR and mass spectroscopy. The monometalated species $\mathbf{3 a}-\mathbf{5 a}$ showed a ${ }^{1} \mathrm{H}$ NMR pattern similar to that described for 1Ir. The ${ }^{13}$ CNMR spectra of the complexes displayed a singlet at low field (about $180 \mathrm{ppm}$ ), confirming that the metalation has occurred. The 2-fold symmetry of the compounds $\mathbf{6}-\mathbf{8}$ is confirmed by the equivalency of the two imidazolylidene rings shown in both ${ }^{1} \mathrm{H}$ and ${ }^{13} \mathrm{C}$ NMR spectra. The protons of the linker chain are diasterotopic due to the lack of a mirror-plane contained on the coordination plane of the molecule. The metalated carbon atoms appear in the region between 175 and $178 \mathrm{ppm}$ [typical for $\operatorname{Ir}(\mathrm{I})-\mathrm{NHC}$ complexes], confirming the $\mathrm{Ir}-\mathrm{C}$ bond formation.

Crystal Structures of $\mathbf{7 b}$ and 8a. Crystals suitable for X-ray diffraction studies were obtained by slow diffusion of $\mathrm{CH}_{2} \mathrm{Cl}_{2} /$ hexane solutions of $\mathbf{7 b}$ and $\mathbf{8 a}$. Figures 2 and 3 show the ORTEP diagram of $\mathbf{7 b}$ and $\mathbf{8 a}$, respectively. The molecular structure of 7b shows that the geometry about the Ir atom is square planar,

Scheme 3

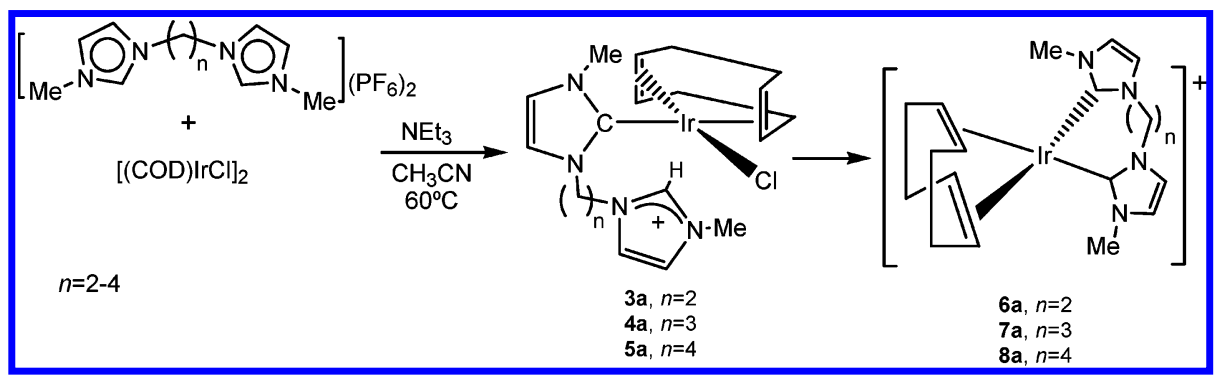


Scheme 4

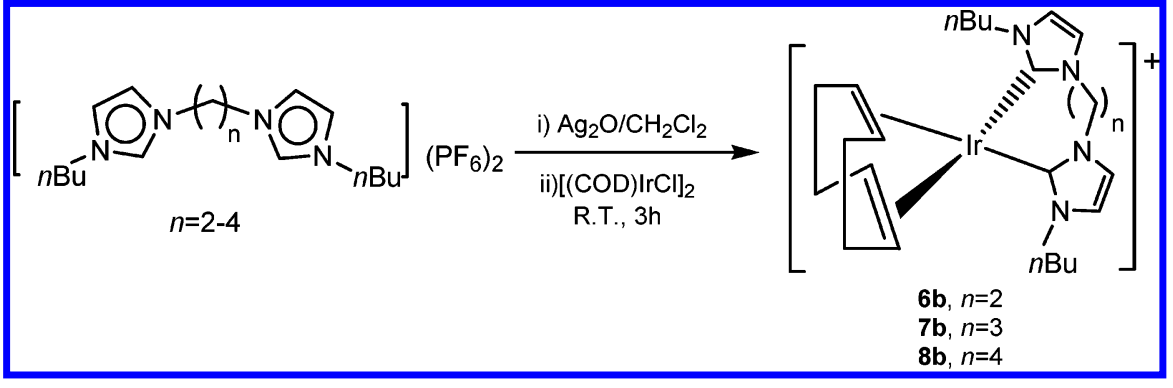

with a chelating bite angle of the bisimidazolylidene ligand of 84.5 . The $\operatorname{Ir}-\mathrm{C}_{\text {carbene }}$ distances are 2.034 and $2.039 \AA$. The macrocyclic eight-membered ring formed by the chelating ligand and the Ir atom adopts a boat-chair conformation, as in cyclooctane. The average angle between the azole rings and the coordination plane of the molecule is $79.9^{\circ}$.

The molecular structure of $\mathbf{8 a}$ shows a distorted square planar geometry around the $\mathrm{Ir}$ atom. The biscarbene bite angle is $93.9^{\circ}$. The $\mathrm{Ir}-\mathrm{C}_{\text {carbene }}$ distances are 2.038 and $2.046 \AA$, similar to other $\mathrm{Ir}-\mathrm{C}_{\text {carbene }}$ distances found for other related NHC-Ir complexes reported in this paper and others. ${ }^{12,17}$ The average angle between the azole planes and the coordination plane of the molecule is $83.0^{\circ}$.

Oxidative Addition of $\mathrm{HCl}$ to 7. To study the possibility that the $\operatorname{Ir}(\mathrm{I})$-bis(NHC) species could give rise to $\mathrm{H}-\mathrm{Ir}(\mathrm{III})$-bis-

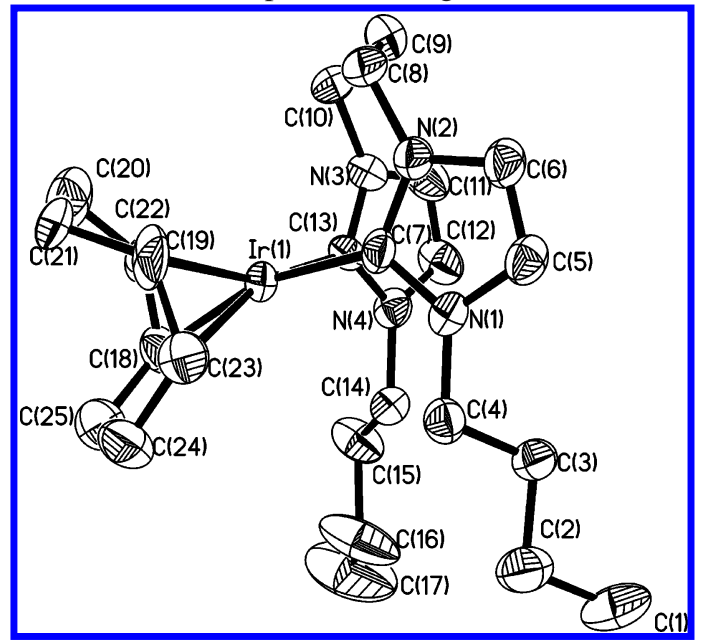

Figure 2. ORTEP diagram of 7b. Hydrogen atoms and counterion $\left(\mathrm{PF}_{6}{ }^{-}\right)$are omitted for clarity. Selected bond distances $(\AA)$ and angles (deg): $\operatorname{Ir}(1)-\mathrm{C}(13)$ 2.034(11), $\operatorname{Ir}(1)-\mathrm{C}(7)$ 2.039(11), C(13)$\operatorname{Ir}(1)-\mathrm{C}(7) 84.5(4)$.

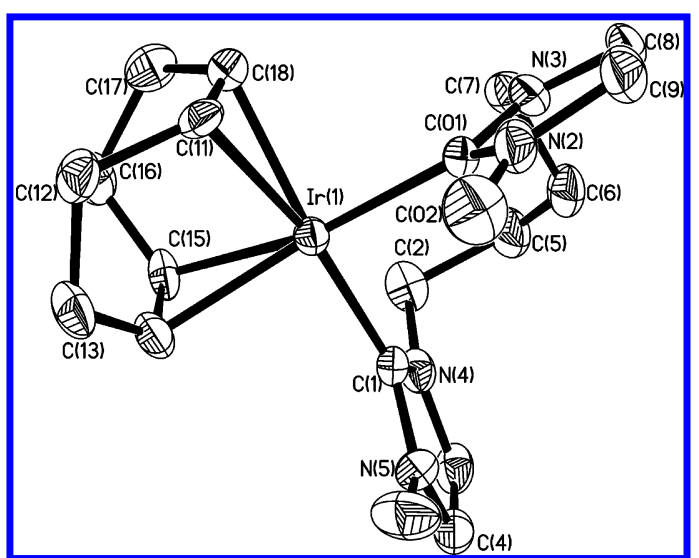

Figure 3. ORTEP diagram of 8a. Hydrogen atoms and counterion $\left(\mathrm{PF}_{6}{ }^{-}\right)$are omitted for clarity. Selected bond distances $(\AA)$ and angles (deg): $\operatorname{Ir}(1)-\mathrm{C}(01) 2.038(7), \operatorname{Ir}(1)-\mathrm{C}(1) 2.046(8), \mathrm{C}(01)-$ $\operatorname{Ir}(1)-\mathrm{C}(1)$ 93.9(3).
(NHC) complexes, similar to $\mathbf{2} \mathbf{I r}$, we decided to study the oxidative addition of $\mathrm{HCl}$ to $\mathbf{7}(\mathbf{7} \mathbf{a}, \mathrm{R}=\mathrm{Me} ; \mathbf{7 b}, \mathrm{R}=n$-Bu). Complex 7a (or 7b) was dissolved in $\mathrm{CH}_{2} \mathrm{Cl}_{2}$, and 2 equiv of $\mathrm{HCl}$ in dioxane was added to the solution, which immediately turned from orange to pale yellow. The reaction product was precipitated by adding hexanes to the reaction mixture, and a pale yellow solid was separated by filtration. The ${ }^{1} \mathrm{H}$ NMR spectrum of the solid showed that it contained a mixture of two hydrides in a 50/50 ratio. Slow crystalization of a solution of the two compounds in a mixture of $\mathrm{CH}_{2} \mathrm{Cl}_{2}$ and $\mathrm{MeOH}$ afforded the separation of crystals that contained only one of the products. The ${ }^{1} \mathrm{H}$ NMR spectrum of $\mathbf{9 a}$ confirmed the existence of a hydride, which displayed its signal at $-27.4 \mathrm{ppm}$. The aliphatic region of the ${ }^{1} \mathrm{H}$ NMR spectrum showed broad signals corresponding to the protons of the azole rings and the propylene chain, thus suggesting a highly fluxional molecule, but the 2 -fold symmetry of the ligand is maintained. The methyl wingtips appear as a singlet at $\delta=3.7$ for the compound obtained from the reaction with $7 \mathbf{a}$. The ${ }^{13} \mathrm{C}$ NMR spectrum reveals that the structure is highly symmetric, and that the coordinated molecule of COD has been lost from the coordination sphere of the molecule. From the NMR data we were unable to conclude the characterization of the molecule. Positive ion ESI-MS analysis revealed peaks at $m / z, 901(\mathbf{9 a})$ and $m / z, 1069(\mathbf{9 b})$, so that we concluded that the product of the oxidative addition of $\mathrm{HCl}$ to 7, is the dimeric $\operatorname{Ir}(\mathrm{III})$ dihydride shown in Scheme 5. This is the first dimetallic Ir(III) hydride with a NHC ligand reported to date and, somehow, challenges the idea that long linker chains disfavor the formation of $\mathrm{M}(\mathrm{III})$ species (M = Rh, Ir).

We believe that the formation of $\mathbf{9 a}$ and $\mathbf{9 b}$ implies that the reaction proceeds via a monometallic NHC-Ir-hydride similar to 2Ir. The high steric hindrance imposed by the 1,5-cyclooctadiene and the bulky NHC planes on the molecule may favor the loss of the COD ligand. A structural rearrangement of the molecule would form the dimetallic compound with an extra $\mathrm{Cl}$ ligand provided by the excess of $\mathrm{HCl}$. Compounds $9 \mathbf{a}$ and 9b are very stable in solution at room temperature, but decompose in the presence of a weak base such as $\mathrm{NEt}_{3}$ or $\mathrm{Cs}_{2}-$ $\mathrm{CO}_{3}$, probably due to a reductive elimination of $\mathrm{HCl}$ that yields a highly unstable molecule.

Crystal Structure of 9a. Crystals suitable for X-ray diffraction studies were obtained by slow evaporation of solutions of 9a in $\mathrm{CH}_{2} \mathrm{Cl}_{2}$, and the results confirmed the structure proposed. Figure 4 shows the ORTEP diagram and the more relevant lengths and angles. The molecular structure of $\mathbf{9 a}$ consists of a 629

(16) Miecznikowski, J. R.; Crabtree, R. H. Organometallics 2004, 23,

(17) Chianese, A. R.; Kovacevic, A.; Zeglis, B. M.; Faller, J. W ; Crabtree, R. H. Organometallics 2004, 23, 2461.

(18) (a) Lee, K. M.; Wang, H. M. J.; Lin, I. J. B. J. Chem. Soc., Dalton Trans. 2002, 2852. (b) Wang, H. M. J.; Lin, I. J. B. Organometallics 1998, 17, 972. (c) Simons, R. S.; Custer, P.; Tessier, C. A.; Youngs, W. J. Organometallics 2003, 22, 1979. (d) Chianese, A. R.; Li, X. W.; Janzen, M. C.; Faller, J. W.; Crabtree, R. H. Organometallics 2003, 22, 1663. 
Scheme 5

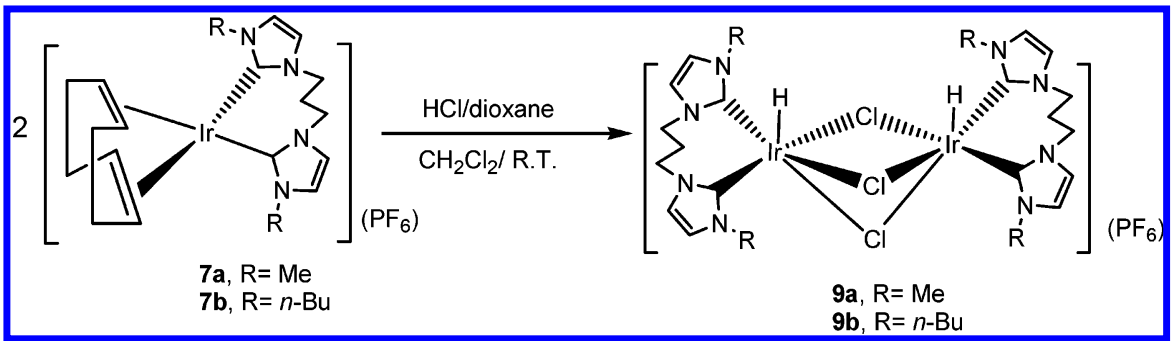

dimetallic unit bridged by three chlorine ligands. One chelating trimethylenebis $(N$-methylimidazole-2-ylidene) ligand and a hydride complete the coordination sphere about each Ir atom. The $\mathrm{Ir}-\mathrm{C}_{\text {carbene }}$ distances range between 1.91 and $1.97 \AA$, a little shorter than other $\mathrm{Ir}-\mathrm{C}_{\text {carbene }}$ distances reported here and in other Ir-NHC complexes. ${ }^{12,17}$ The biscarbene bite angles of $88.4^{\circ}$ and $93.6^{\circ}$ are close to that expected for an ideal octahedral coordination $\left(90^{\circ}\right)$. The $\mathrm{Ir}-\mathrm{Ir}$ distance is $3.33 \AA$, which discards any possibility of a bonding interaction. The relative disposition of the two biscarbene ligands and the hydrides is syn, with the methylene bridging fragments and the two hydrides adopting an eclipsed conformation. The two hydride ligands are trans to the same bridging $\mathrm{Cl}$ ligand $(\mathrm{Cl}(3)$ in Figure 4$)$. The heterocyclic imidazole-2-ylidene rings and the equatorial coordination plane of the complex (defined for each Ir fragment by the two metalated atoms, the metal, and two of the chlorine bridges) range from $69^{\circ}$ to $73^{\circ}$.

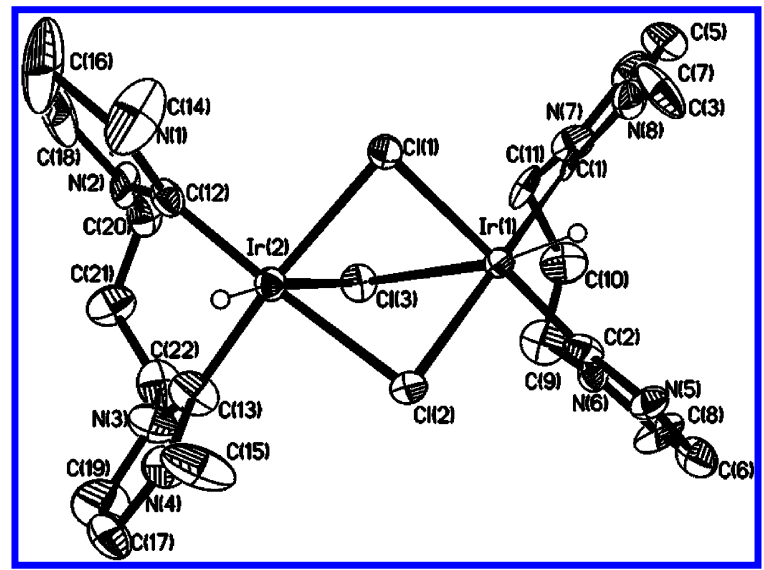

Figure 4. ORTEP diagram of 9a. Hydrogen atoms and counterion $\left(\mathrm{PF}_{6}{ }^{-}\right)$are omitted for clarity. Selected bond distances $(\AA)$ and angles (deg): $\operatorname{Ir}(1)-\mathrm{H}(1)$ 1.80(17), $\operatorname{Ir}(1)-\mathrm{C}(1)$ 1.97(3), $\operatorname{Ir}(1)-\mathrm{C}(2)$ 1.95(3), $\operatorname{Ir}(2)-\mathrm{H}(2)$ 1.45(16), $\operatorname{Ir}(2)-\mathrm{C}(13)$ 1.91(3), $\operatorname{Ir}(2)-\mathrm{C}(12)$ 1.94(3), C(1)- $\operatorname{Ir}(1)-\mathrm{C}(2) 88.4(9), \mathrm{C}(13)-\operatorname{Ir}(2)-\mathrm{C}(12) 93.6(11)$.

In view of the molecular structure of $9 \mathbf{a}$, we believe that the oxidative addition of $\mathbf{7 a}$ and $\mathbf{7 b}$ may yield two similar complexes in which the only difference is the relative disposition of the ligands: syn (in 9a and 9b) and anti (relative to the two hydride ligands). We have not been able to isolate the anti isomer, but may have detected it in a 1:1 ratio in the preparation of $9 \mathbf{a}$ and $\mathbf{9 b}$, as described above.

Theoretical Study of the Mechanism of NHC Generation. To cast light on the reaction mechanism and the origin of the observed selectivity for either octahedral or square planar products depending on the carbene linker length, calculations were carried out on the free ligands and their related complexes. Methyl groups on the nitrogen atoms of the azolium salts were replaced by hydrogens (ligands shown in Scheme 6). Test calculations were performed to check the influence of this approximation in the acid-base properties of the ligands. Both

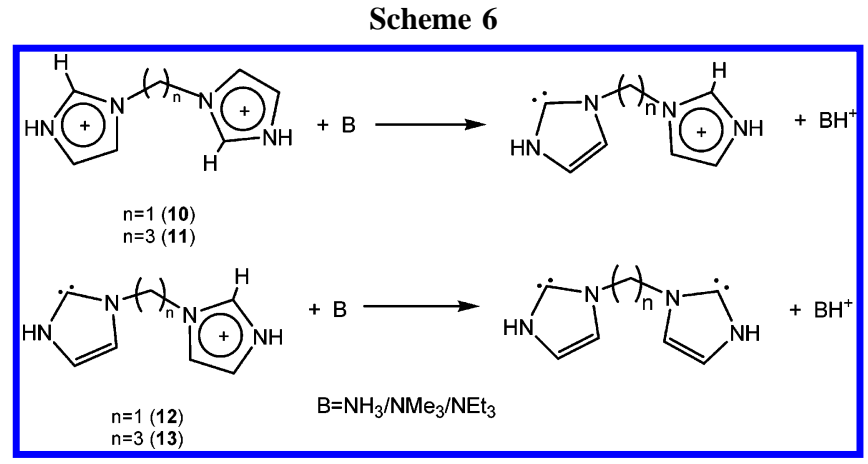

the short linker $\left(C_{1}\right)$ and the long linker $\left(C_{3}\right)$ cases were taken into account.

(1) NHC Ligand Deprotonation vs. Oxidative Addition (General Considerations). The first step was to examine the deprotonation reactions of the isolated azolium cations 10-13 by three different weak bases $\mathrm{B}\left(\mathrm{B}=\mathrm{NH}_{3}, \mathrm{NMe}_{3}, \mathrm{NEt}_{3}\right.$ ), to get information about their proton affinities.

Reactants and product optimizations were carried out in the gas phase, while the energies were also evaluated in acetonitrile solvent by means of single-point calculations with a continuum model of the solvent. In the gas phase the first deprotonation step always is very favorable (exothermic reactions with all the bases considered), and the stabilities of the final products increase with the strength of the base, as expected: values of $\Delta E=-30.7 \mathrm{kcal} / \mathrm{mol}$ for ammonia, $-50.1 \mathrm{kcal} / \mathrm{mol}$ for trimethylamine, and $-57.0 \mathrm{kcal} / \mathrm{mol}$ for triethylamine in the deprotonation of $\mathbf{1 0}$ are obtained. The negative value of $\Delta E$ can be traced to the separation of two positive (repulsive) charges, a phenomenon always spontaneous in vacuo. On the contrary, in the gas phase the second step is highly endothermic; again the stronger the base, the more feasible the reaction. $\Delta E$ values for deprotonation of $\mathbf{1 2}$ are as follows: $+56.9,+37.5$, and $+30.6 \mathrm{kcal} / \mathrm{mol}$ for ammonia, trimethylamine, and triethylamine, respectively. The positive charge is better delocalized on the imidazolium system than on a small (and saturated) molecule like $\mathrm{HNR}_{3}{ }^{+}$; therefore, proton transfer to the base as depicted is unfavorable. The presence of $\mathrm{CH}_{3} \mathrm{CN}$ as solvent makes the first deprotonation much more unfavorable and decreases the endothermicity of the second step, both steps now being endothermic and close in energy. Values of $+23.1 /+28.2$ $\mathrm{kcal} / \mathrm{mol}$ are obtained for reactions of $\mathbf{1 0 / 1 2}$ with ammonia, while $+20.1 /+25.2$ and $+16.1 /+21.2 \mathrm{kcal} / \mathrm{mol}$ are obtained with $\mathrm{NMe}_{3}$ and $\mathrm{NEt}_{3}$, respectively. Reorganization of the acetonitrile molecules around two (singly charged) bodies implies an excess of energy higher than that around one (doubly charged) body. Results in the cases $\mathrm{C}_{1}$ and $\mathrm{C}_{3}$ are similar. No substantial differences in the proton affinities of the short linker and the long linker imidazoliums were found, as well as the overall thermodynamics (i.e., the first deprotonation is favorable, while the second one is unfavorable in the gas phase, while both are unfavorable in acetonitrile). For example, the following values 
Scheme 7

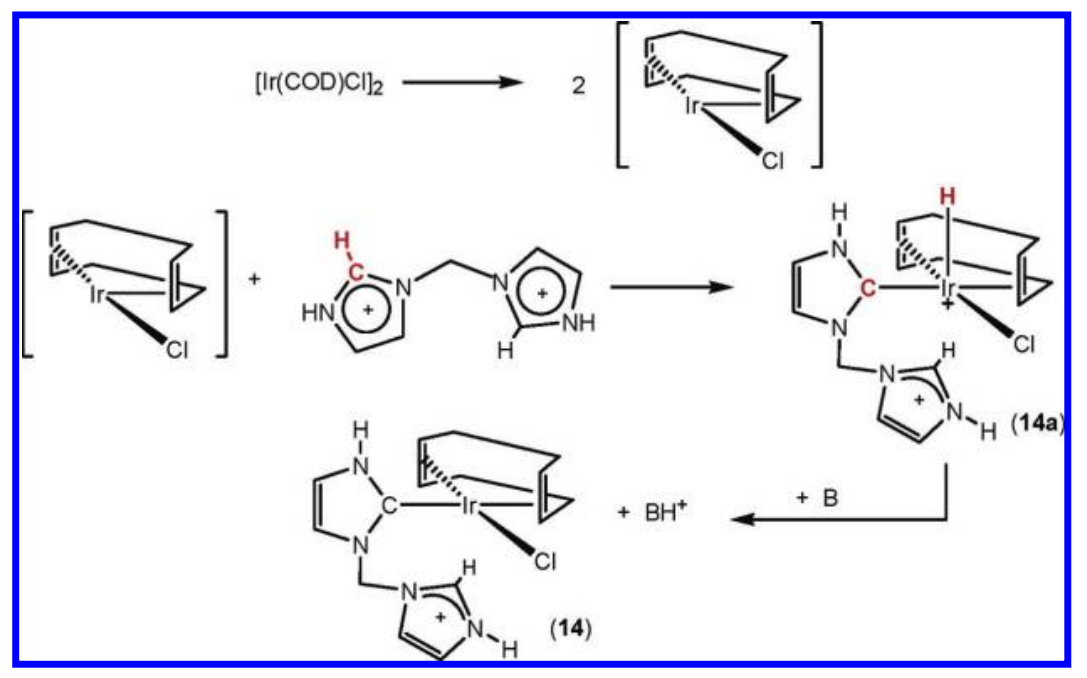

were obtained for $\Delta E$ 's of reaction of $\mathbf{1 1 / 1 3}$ with $\mathrm{NMe}_{3}$ : -34.4 / $+49.5 \mathrm{kcal} / \mathrm{mol}$ in the gas phase and $+25.9 /+29.2$ in acetonitrile. We checked if the replacement of the actual alkyl chains on the $\mathrm{N}$ peripheral atoms of the azolium salt with hydrogen atoms changes the acid-base properties of the ligands. Values of +14.8 and $+19.8 \mathrm{kcal} / \mathrm{mol}$ are obtained for $\Delta E$ of deprotonation of 10-Me and 12-Me (cations 10 and 12 bearing methyl groups on the terminal $\mathrm{N}$ atoms) with $\mathrm{NEt}_{3}$ in acetonitrile (cf. the related values for 10/12: $+16.1 /+21.2 \mathrm{kcal} / \mathrm{mol}$, respectively). We conclude that modeling the $\mathrm{R}$ substituents on the $\mathrm{N}$ atoms by $\mathrm{H}$ does not alter the electronic properties of the ligand significantly.

Another alternative that was taken into account to decrease the thermodynamic energy differences for the first carbene formation was coordination of $\mathbf{1 0}$ or $\mathbf{1 1}$ through one of their $\mathrm{C}(2)-\mathrm{H}$ bonds to the neutral metal fragment "(COD) $\operatorname{Ir}(\mathrm{Cl})$ ", derived from the dissociation of the dimeric precursor [(COD)$\mathrm{IrCl}_{2}$. Eventual formation of a $\sigma(\mathrm{C}-\mathrm{H})$ agostic complex would make the hydrogen atom more acidic, and deprotonation easier. The analysis was performed only for the $C_{1}$ case (cation 10). Nevertheless, optimization of this adduct led to $\mathrm{C}-\mathrm{H}$ oxidative addition on iridium(I) (with related $\mathrm{C}-\mathrm{H}$ bond cleavage) instead of a $\sigma(\mathrm{C}-\mathrm{H})$ agostic complex. The final structure 14a (Scheme 7 ) is five-coordinated, with a square pyramidal ligand arrangement, where the $\mathrm{H}$ atom occupies the pyramid apex. Deprotonation of 14a with $\mathrm{NEt}_{3}$ gives the precursor 14, and the overall $\Delta E$ for the process depicted in Scheme 7 was found to be -8.5 $\mathrm{kcal} / \mathrm{mol}$ in acetonitrile. From these results, we can infer that initial interaction of the azolium with the metal center makes the first carbene formation much more facile (cf. the value obtained for a "metal-free" first deprotonation of 10: $\Delta E=$ $+16.1 \mathrm{kcal} / \mathrm{mol}$ in acetonitrile). Deprotonation by $\mathrm{NEt}_{3}$ of the acidic $\mathrm{C}(2)-\mathrm{H}$ bond of the coordinated azolium in 14a is endothermic by $17.6 \mathrm{kcal} / \mathrm{mol}$ in acetonitrile, much more unfavorable than the reaction with the metal hydride. Thus, we can assume that only the last one is taking place.

Second, the same deprotonation process was considered, starting from the azolium monocation $\mathbf{1 2}$ or $\mathbf{1 3}$ coordinated in the square planar $\operatorname{Ir}(\mathrm{I})$ complexes $\mathbf{1 4}$ and $\mathbf{1 5}$ shown in Scheme 8 , to see if coordination modifies the azolium acidic properties.

The reaction was studied again both in the gas phase and in acetonitrile. For the former case, it always appears to be highly endothermic $(\Delta E=+65.9,+46.1$, and $+39.8 \mathrm{kcal} / \mathrm{mol}$ for reaction of $\mathbf{1 4}$ with ammonia, trimethylamine, and triethylamine, respectively). The stronger the base, the smaller the energy

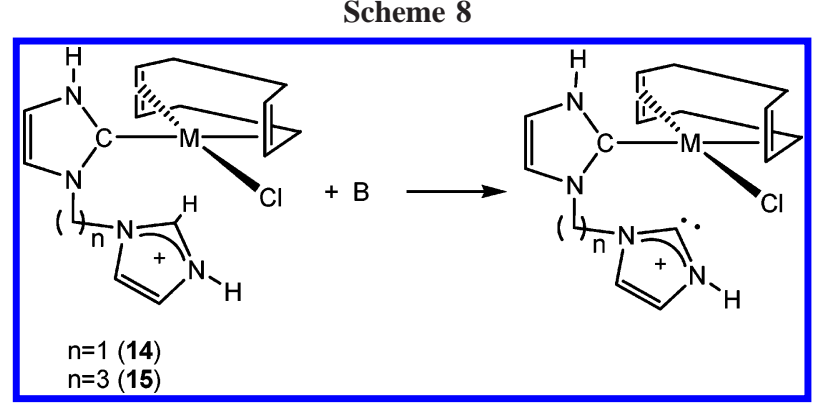

difference, as expected, since a stronger base makes the reaction more feasible. The deprotonation is even more difficult than in the isolated azolium salt (cf. these values with those obtained for the free 12). The same conclusion can be drawn for the long linker case, where similar results were obtained for complex $15(\Delta E=+66.6,+46.8$, and $+40.4 \mathrm{kcal} / \mathrm{mol})$. In the $C_{3}$ case though, the process seems to be slightly favored if the azolium is coordinated: compare the $+46.8 \mathrm{kcal} / \mathrm{mol}$ value of 15 with the $+49.5 \mathrm{kcal} / \mathrm{mol}$ one for the free $\mathbf{1 3}$ using the same base $\left(\mathrm{NMe}_{3}\right)$. Thermodynamics in acetonitrile is much more favorable, due to the strong ion stabilization in a polar solvent $(\Delta E=+26.2$ in acetonitrile $v s .+40.4 \mathrm{kcal} / \mathrm{mol}$ in vacuo, for deprotonation of $\mathbf{1 5}$ with triethylamine, and +22.6 vs. +39.8 $\mathrm{kcal} / \mathrm{mol}$ for the same reaction on 14). However, even in a polar solvent the deprotonation of the coordinated NHC by an alkylamine appears as a very endothermic process. Again, the presence of hydrogen atoms instead of $\mathrm{R}$ groups on the peripheral $\mathrm{N}$ atoms in the model cations does not change deprotonation thermodynamics drastically, as already seen for the free ligand. As for the reaction of $14-\mathrm{Me}$ with $\mathrm{NEt}_{3}$ in acetonitrile, $\Delta E=+21.4 \mathrm{kcal} / \mathrm{mol}$ is calculated, while the related value for $\mathbf{1 4}$ is $+22.6 \mathrm{kcal} / \mathrm{mol}$.

Judging from these results, we find it difficult to discern whether the "diazolium" species $\mathbf{1 0}$ and $\mathbf{1 1}$ form the monocarbene species 14 and 15 via reaction with a base (deprotonation prior to coordination to metal) or via oxidative addition of the $\mathrm{C}-\mathrm{H}$ bond and then deprotonation of the metal hydride (reductive elimination) with the base, since both processes are thermodynamically feasible. We have experimentally seen that addition of a weak base $\left(\mathrm{NEt}_{3}, \mathrm{NMe}_{3}, \mathrm{AcNa}\right)$ to a sample of methylenebis $(N$-methylimidazolium) hexafluorophosphate (or trimethylenebis ( $N$-methylimidazolium) hexafluorophosphate) in $\mathrm{CD}_{3} \mathrm{CN}$ results in the monodeprotonation of the compound to generate the monocarbene species. However, we do not have 
Scheme 9

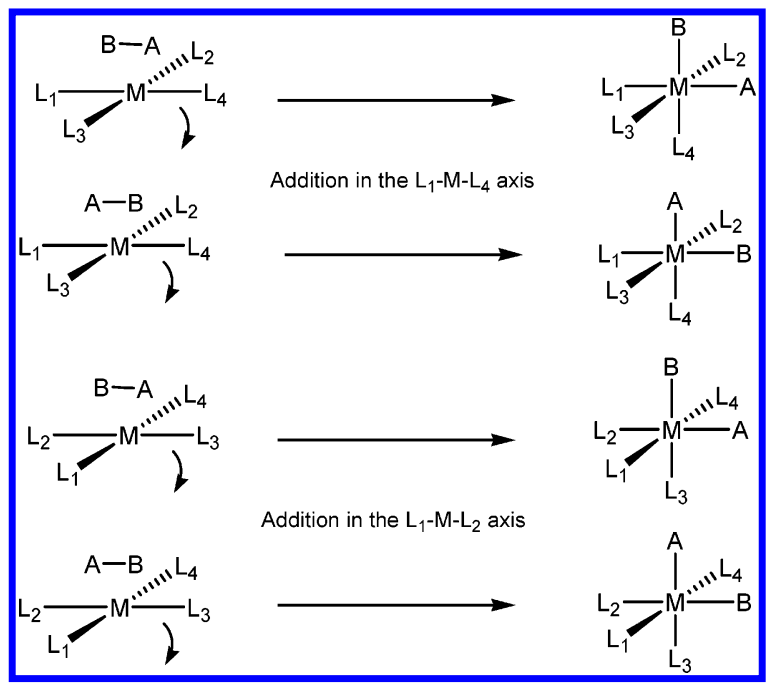

any experimental evidence on the role of the metal in the deprotonation process; so from our point of view this result does not discard the possibility of a $\mathrm{C}-\mathrm{H}$ oxidative addition to the metal.

For the second metalation step, the formation of the biscarbene is much more difficult via direct deprotonation with the base, for both the $\mathrm{C}_{1}$ and the $\mathrm{C}_{3}$ cases, even when the monocarbene is coordinated to a metal center. In this case, formation of a carbene via $\mathrm{C}-\mathrm{H}$ oxidative addition on the metal center itself was then considered, to check whether this option shows lower energy products and barriers than the deprotonation path.

(2) C-H Oxidative Addition (Second Metalation). General Considerations. The oxidative addition of $\mathrm{H}-\mathrm{H}$ to square planar $\operatorname{Ir}(\mathrm{I})$ and $\mathrm{Rh}(\mathrm{I})$ complexes has been extensively studied. ${ }^{19,20}$ This reaction is thought to be a one-step reaction leading to a cis dihydride product with a pseudooctahedral structure. In complexes where the symmetry is neither $C_{2 v}$ nor $D_{4 h}$, the concerted addition of $\mathrm{H}_{2}$ yields two possible structural isomers, depending along which diagonal ligand axis of the square planar complex the $\mathrm{H}_{2}$ unit adds. For the general case of an "A-B" oxidative addition the final six-coordinated octahedral product can exist in four different stereoisomers, depending on which $\mathrm{L}-\mathrm{M}-\mathrm{L}^{\prime}$ axis the $\mathrm{A}-\mathrm{B}$ is parallel to in the transition state, and the orientation of the $A-B$ vector (Scheme 9). It is assumed that the substituents A and B will always be cis to each other in the octahedron after the addition.

The Thermodynamic Aspect: Relative Stabilities of the Products. Applying the general scheme to the specific case of complex 14 or $\mathbf{1 5}$, with chelating ligands, some of the cases depicted in Scheme 9 had to be excluded, since the final ligand disposition around the metal center is not completely free. A cis disposition was assumed for the two olefinic groups of the COD ligand, as well as for the final chelating carbene. Thus, only three isomers are possible when the $\mathrm{C}-\mathrm{H}$ bond of the azolium ion is added to iridium(I) (Scheme 10).

The first isomer would have a trans coordination mode for the chelating carbene moiety; therefore it was excluded from the analysis. As a consequence, two cis- $(\mathrm{H}, \mathrm{Cl})$ and one trans-

(19) (a) Jean, Y.; Lledós, A. New J. Chem. 1986, 10, 635. (b) Sargent, A. L.; Hall, M. B.; Guest, M. F. J. Am. Chem. Soc. 1992, 114, 517. (c) Suardi, G.; Cleary, B. P.; Duckett, S. B.; Sleigh, C.; Rau, M.; Reed, E. W.; Lohman, J. A. B.; Eisenberg, R. J. Am. Chem. Soc. 1997, 119, 7716. (d) Deutsch, P. P.; Eisenberg, R. Chem. Rev. 1988, 88, 1147.

(20) Sargent, A. L.; Hall, M. B. Inorg. Chem. 1992, 31, 317.

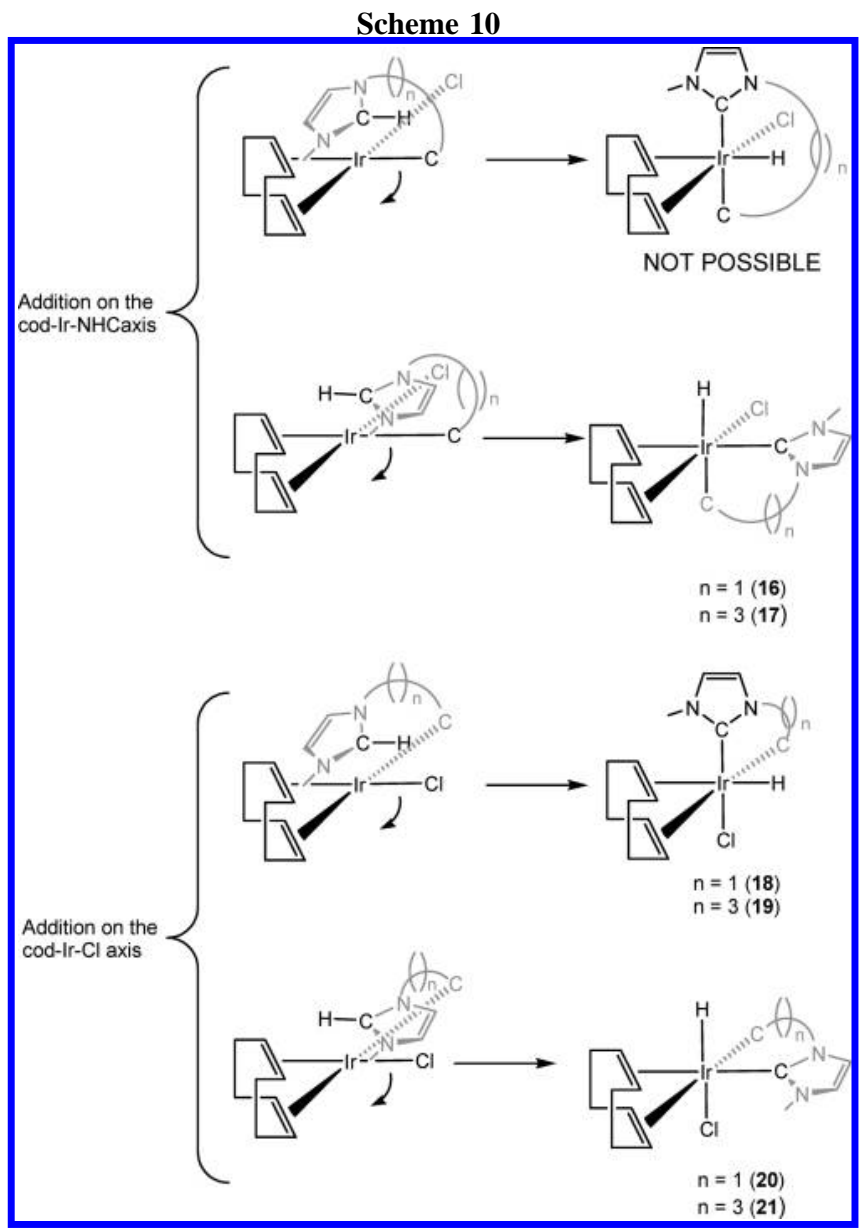

$(\mathrm{H}, \mathrm{Cl})$ isomers are the final products, both for the $\mathrm{C}_{1}$ and the $\mathrm{C}_{3}$ cases. Figures 5 and 7 show the optimized geometries of the square planar reagent and its related three octahedral products for the $\mathrm{C}_{1}$ and the $\mathrm{C}_{3}$ linker carbene complexes, respectively. The calculated structures show a fairly good agreement with the experimental bond lengths and angles coming from XRD, when available: Table 1 collects the most relevant calculated and experimental structural parameters for complex 20 and the parent species 2Ir (Figure 1).

Figures 6 and 8 give a schematic representation of the energy profile for the $\mathrm{C}-\mathrm{H}$ oxidative addition leading to the $\mathrm{C}_{1}$ and

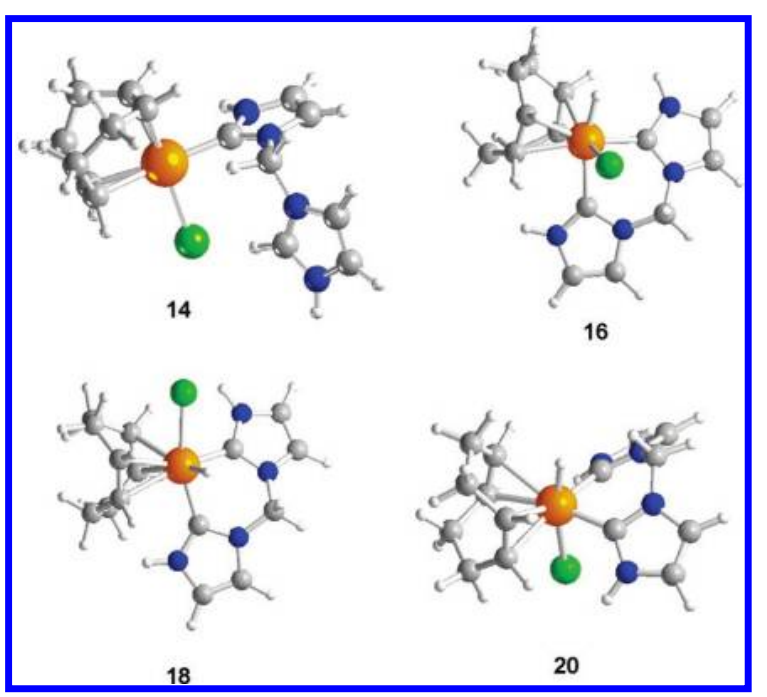

Figure 5. Optimized structures of the short linker $C_{1}$ carbene complexes studied. 


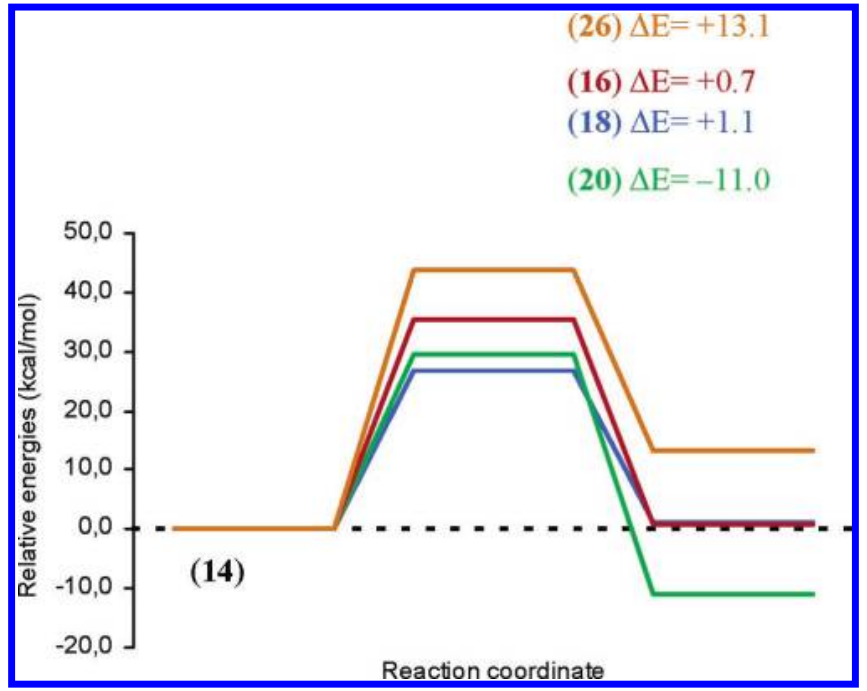

Figure 6. Energy scheme for the formation of the $C_{1}$ carbene complexes studied (refer to Scheme 10 for molecule numbering).

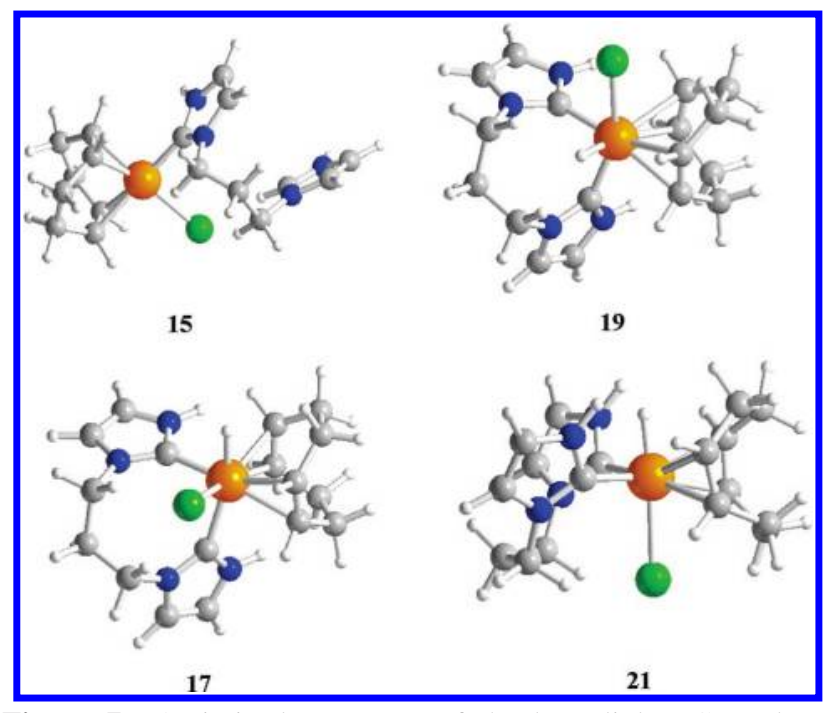

Figure 7. Optimized structures of the long linker $\mathrm{C}_{3}$ carbene complexes studied.

Table 1. Optimized and X-ray-Determined Bond Lengths (A) and Angles (deg) for 20 and 2Ir (refer to Figure 1 for atom numbering)

\begin{tabular}{lcc}
\hline \multicolumn{1}{c}{ parameter } & experimental value (2Ir) & calculated value (20) \\
\hline $\operatorname{Ir}(1)-\mathrm{H}(1)$ & $1.64(9)$ & 1.585 \\
$\operatorname{Ir}(1)-\mathrm{C}(2)$ & $2.048(5)$ & 2.019 \\
$\operatorname{Ir}(1)-\mathrm{C}(6)$ & $2.056(5)$ & 2.021 \\
$\operatorname{Ir}(1)-\mathrm{Cl}$ & $2.494(1)$ & 2.551 \\
$\mathrm{H}(1)-\operatorname{Ir}(1)-\mathrm{Cl}$ & $161(3)$ & 168.7 \\
$\mathrm{C}(2)-\operatorname{Ir}(1)-\mathrm{C}(6)$ & $84.64(19)$ & 83.1
\end{tabular}

$\mathrm{C}_{3}$ linkers, respectively. Regarding the thermodynamics of the process, the trans- $(\mathrm{H}, \mathrm{Cl})$ isomer always appears to be the most stable, the reaction being considerably more exothermic in the case of the short linker $(\Delta E=-11.0$ and $-0.7 \mathrm{kcal} / \mathrm{mol}$ for formation of $\mathbf{2 0}$ and $\mathbf{2 1}$, respectively).

The two possible cis- $(\mathrm{H}, \mathrm{Cl})$ isomers (always assuming a cis coordination for both the carbene and the COD ligand in the octahedron) that can be obtained from the $\mathrm{C}-\mathrm{H}$ addition lie much higher in energy, with very different relative stabilities depending on the $\mathrm{C}_{n}$ linker. There is only $0.4 \mathrm{kcal} / \mathrm{mol}$ difference between 16 and 18 , but a $7.4 \mathrm{kcal} / \mathrm{mol}$ difference is found between 17 and 19. We have analyzed if these differences are intrinsic to the ligand or are originated by the ligand coordination, performing a single-point calculation of the energies of

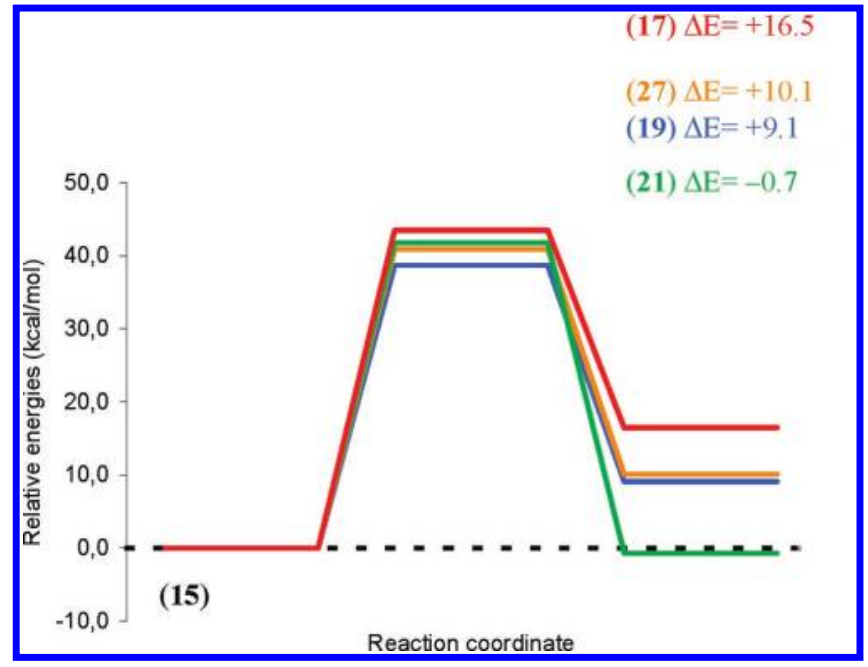

Figure 8. Energy scheme for the formation of the $\mathrm{C}_{3}$ carbene complexes studied (refer to Scheme 10 for molecule numbering).

the bare ligands with the same conformation they have in the complexes. Their energies do not appear to depend on the carbene ligand conformation, because the energies of the bare ligands are identical for the two cis isomers, both in the $\mathrm{C}_{1}$ and the $\mathrm{C}_{3}$ cases. Thus, the ligand is "innocent" from this point of view. Besides that, the bite angles of the chelating carbenes $\mathrm{C}_{1}$ and $\mathrm{C}_{3}$ in the complexes are similar $\left(85.9^{\circ}\right.$ and $86.5^{\circ}$ for $\mathbf{1 6}$ and 18, respectively, $84.2^{\circ}$ and $83.9^{\circ}$ for 17 and 19), no matter the complex or the linker. The conformations of the ligands have been taken directly from the XRD structures of the ferrocenyl carbene analogue (after ferrocene and $N$-methyl group replacement with hydrogens) for the $\mathrm{C}_{1}$ case (see Scheme 1) and the square planar $\mathbf{7 b}$ for the $\mathrm{C}_{3}$ case (Figure 2, replacing the $N$-butyl groups with hydrogens). Ligand conformations were the same for all the calculations; thus the choice of a "particular" one does not influence the relative energy values. The origin of the energy differences between the isomers in a $\mathrm{C}_{1}$ vs. $\mathrm{C}_{3}$ comparison is probably related to the different "flexibility" of the $\mathrm{C}_{1}$ and the $\mathrm{C}_{3}$ carbenes. The short-linker ligand is more rigid, thus influencing the "conformational freedom" it may have in forming the complexes. The different strain present in the various complexes causes the variation of the relative energies. An explanation of the different stabilities of the cis- and trans$(\mathrm{H}, \mathrm{Cl})$ isomers could lie in the trans influence of the hydride, chloride, carbene, and ethylene ligands. Key parameters are the $\mathrm{H}-\mathrm{Ir}-\mathrm{C}(\mathrm{NHC})$ angles in the various species: since the hydride and the NHC ligands are the strongest $\sigma$-donors, the energy is lower when they are cis to each other (angle close to $90^{\circ}$ ) rather than trans (angle close to $\left.180^{\circ}\right)$. Therefore, in the trans- $(\mathrm{H}, \mathrm{Cl})$ isomers 20 and $\mathbf{2 1}$ the situation is the best one, since the two $\mathrm{H}-\mathrm{Ir}-\mathrm{C}$ angles are $86.1^{\circ} / 86.4^{\circ}$ and $82.8^{\circ} / 82.6^{\circ}$, respectively, while in $\mathbf{1 6}$ or 17 values of $84.0^{\circ} / 163.2^{\circ}$ and $85.2^{\circ} / 163.2^{\circ}$ are found.

Additional proof for the prevailing role of electronic factors on the product stabilities comes from the analysis of the model reaction of oxidative addition of $\mathrm{C}-\mathrm{H}$ from methane to a simple $\operatorname{Ir}(\mathrm{I})$ square planar complex, as depicted in Scheme 11. The reasons to study this model were twofold: (a) to investigate the relative importance of electronic and steric effects in the reaction and (b) to check the validity of the computational methodology used. For the first point, the COD ligand of the real system was replaced by two ethylene ligands, and the coordinated NHC carbene by a simple $=\mathrm{CH}_{2}$. The $\mathrm{C}-\mathrm{H}$ bond added is coming from methane, the smallest species conceivable containing such a bond. With these replacements, the steric 
Scheme 11

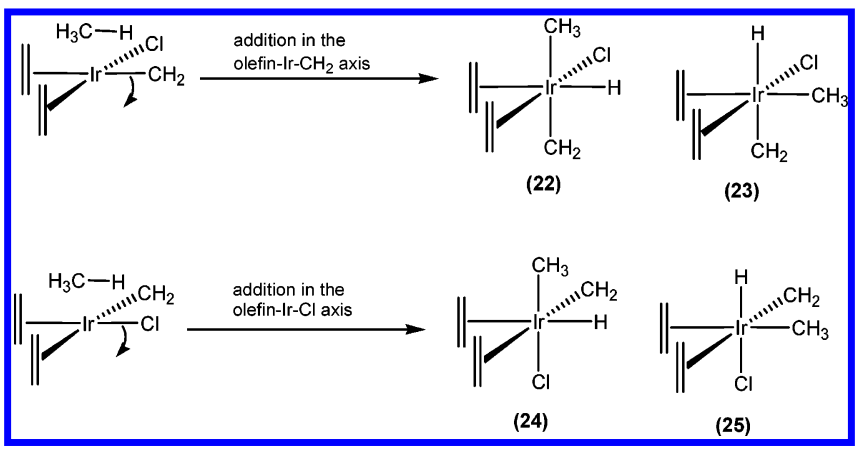

effects are minimized, and it is thus possible to highlight only the electronic ones. Figure 9 shows the energy scheme for the model system.

In this case, since the final product does not contain any chelating ligand, all the possible isomers were taken into account (isomer $\mathbf{2 2}$ is the analogue of the "forbidden" product in the real molecule). In this simple system the oxidative addition is much more endothermic than in our real systems. However, the energy ordering of the products is maintained, and the trans$(\mathrm{H}, \mathrm{Cl})$ product $\mathbf{2 5}$ is also thermodynamically favored. The final octahedral cis- $(\mathrm{H}, \mathrm{Cl})$ products $\mathbf{2 3}$ and $\mathbf{2 4}$ have relative energies that are similar to those obtained in the $\mathrm{C}_{3}$ case $(\Delta E(\mathbf{2 3}-\mathbf{2 4})=$ $14 \mathrm{kcal} / \mathrm{mol}$ ). This was expected, because the longer the linkers, the closer the system to a "strain-free" addition, like that of the model reaction. For this simple model no steric hindrance is present, thus indicating that the final energies are mainly influenced by electronic rather than steric factors. Finally, these factors do not seem to depend on the ligand conformation within the complex; they have to be ascribed to the carbenes themselves.

The small system allowed to assess the validity of the computational method employed, by obtaining CCSD(T) singlepoint energies at the DFT-optimized geometries for all the species of Scheme 11. The DFT energies are in very good agreement with the $\operatorname{CCSD}(\mathrm{T})$ results $\left\{[\Delta E(\mathbf{2 3}-\mathbf{2 4})]_{\mathrm{DFT}}=14\right.$

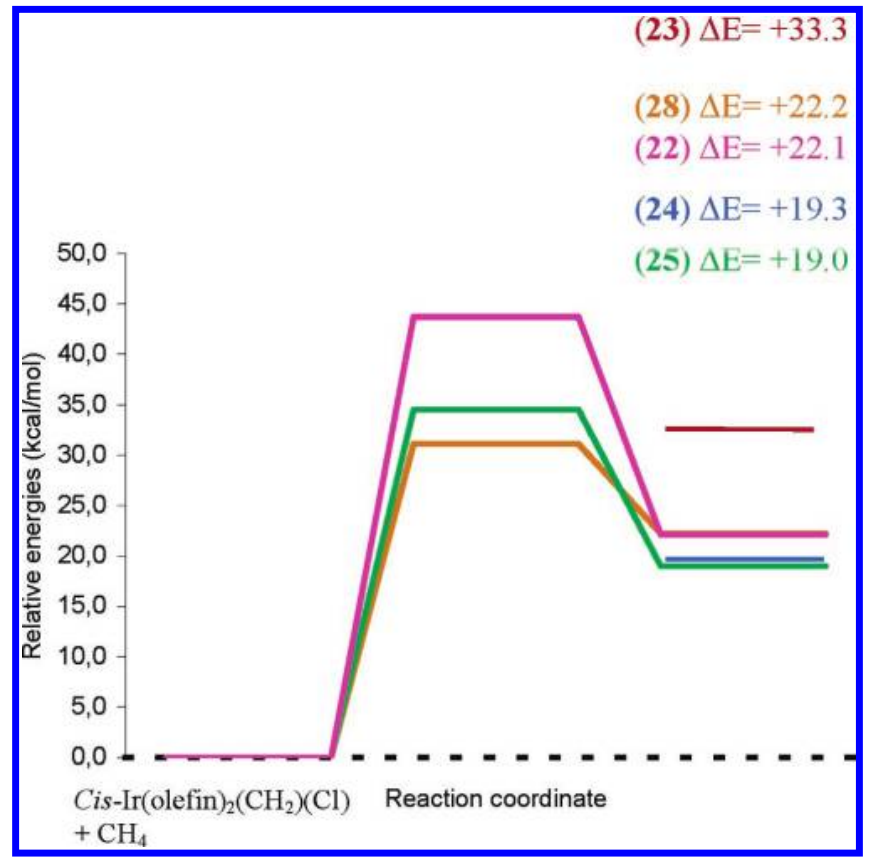

Figure 9. Energy scheme for the formation of the model complexes of study. Only the TSs for formation of $\mathbf{2 2 , 2 5}$, and $\mathbf{2 8}$ were found (refer to Scheme 11 for molecule numbering).
Table 2. Main Parameters for the Transition States of $\mathbf{C}-\mathbf{H}$ Oxidative Addition on 14 and 15

\begin{tabular}{lcccccr}
\hline & $\begin{array}{c}\Delta E^{\#} \\
(\mathrm{kcal} / \mathrm{mol})\end{array}$ & $\begin{array}{c}d(\mathrm{Ir}-\mathrm{H}) \\
(\AA)\end{array}$ & $\begin{array}{c}d(\mathrm{Ir}-\mathrm{C}) \\
(\AA)\end{array}$ & $\begin{array}{c}d(\mathrm{C}-\mathrm{H}) \\
(\AA)\end{array}$ & $\begin{array}{c}\alpha \\
(\mathrm{deg})\end{array}$ & $\begin{array}{c}\theta \\
(\mathrm{deg})\end{array}$ \\
\hline $\mathbf{T S}_{\mathbf{1 4} \rightarrow \mathbf{1 6}}$ & 35.4 & 1.783 & 2.174 & 1.296 & 119.2 & 33.4 \\
$\mathbf{T S}_{\mathbf{1 4} \rightarrow \mathbf{1 8}}$ & 26.7 & 1.812 & 2.085 & 1.316 & 115.6 & 23.8 \\
$\mathbf{T S}_{\mathbf{1 4} \rightarrow \mathbf{2 0}}$ & 29.5 & 1.856 & 2.414 & 1.189 & 126.3 & 7.4 \\
$\mathbf{T S}_{\mathbf{1 5} \mathbf{1 7}}$ & 43.5 & 1.764 & 2.197 & 1.321 & 116.2 & 20.8 \\
$\mathbf{T S}_{\mathbf{1 5} \rightarrow \mathbf{1 9}}$ & 38.7 & 1.737 & 2.151 & 1.344 & 118.8 & 34.3 \\
$\mathbf{T S}_{\mathbf{1 5} \rightarrow \mathbf{2 1}}$ & 41.8 & 1.702 & 2.458 & 1.302 & 120.1 & 26.7
\end{tabular}

$\mathrm{kcal} / \mathrm{mol},[\Delta E(\mathbf{2 3}-\mathbf{2 4})]_{\mathrm{CCSD}(\mathrm{T})}=15.1 \mathrm{kcal} / \mathrm{mol} ;[\Delta E(\mathbf{2 4}-\mathbf{2 5})]_{\mathrm{DFT}}$ $\left.=0.3 \mathrm{kcal} / \mathrm{mol},[\Delta E(\mathbf{2 4}-\mathbf{2 5})]_{\mathrm{CCSD}(\mathrm{T})}=0.2 \mathrm{kcal} / \mathrm{mol}\right\}$, thus making the whole analysis reliable.

The Kinetic Aspect: Energy Barriers and Transition States. The transition states for all the reactions drawn in Scheme 10 were found, together with the related barriers (evaluated from 14 or 15). In both the $C_{1}$ and the $C_{3}$ cases, a "crossing" between the trans- $(\mathrm{H}, \mathrm{Cl})$ and one specific cis- $(\mathrm{H}, \mathrm{Cl})$ isomer was observed, where the barrier for formation of the former (the more stable thermodynamic product) is higher than that of the latter (less stable; it can thus be considered the kinetic product). The kinetic product has the hydride ligand trans to one olefin group, corresponding to complex 18 or 19. The barriers found for the other cis- $(\mathrm{H}, \mathrm{Cl})$ species (16 or 17), with the hydride substituent trans to a carbene, are the highest. This crossing was already observed in the $\mathrm{H}_{2}$ oxidative addition to $\operatorname{Ir}(\mathrm{I})^{20}$ and also in the $\mathrm{C}-\mathrm{H}$ addition of azolium salts to $\mathrm{Ni}(0)$, $\operatorname{Pd}(0)$, and $\operatorname{Pt}(0)$ square planar complexes. ${ }^{13}$

Table 2 collects all the relevant structural parameters and relative energies of the transition states encountered, and Figures 10 and 11 show the optimized TS structures for the two linkers.

The angle $\alpha$ is defined as the bending angle (olefin- $\mathrm{Ir}-\mathrm{E}$ ), where E can be either chlorine or a carbenic carbon (Scheme 12). In a square planar complex $\alpha=180^{\circ}$, while in transition structures it is generally around $120^{\circ}$, the latter value corresponding to a five-coordinated iridium in a bipyramidal trigonal geometry, where the $\mathrm{C}-\mathrm{H}$ bond occupies one equatorial position.

$\theta$ is the dihedral angle $(\mathrm{E}-\mathrm{Ir}-\mathrm{C}-\mathrm{H})$; it is the angle between the (olefin- $\mathrm{Ir}-\mathrm{E}$ ) and the $\mathrm{C}-\mathrm{H}$ bond directions (Scheme 13). If the $\mathrm{C}-\mathrm{H}$ and $\mathrm{Ir}-\mathrm{L}$ bonds were perfectly parallel, $\theta=0^{\circ}$; in the species found there are deviations from the "ideal" situation. Structural analysis of the TS geometries shows that the $\mathrm{C}-\mathrm{H}$ bond is not exactly parallel to the diagonal of the squared

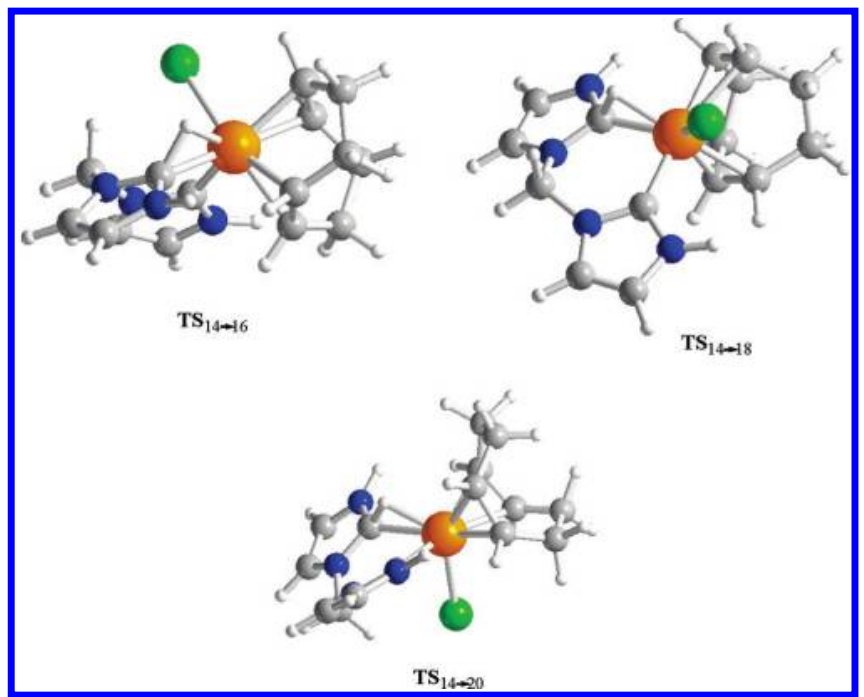

Figure 10. Optimized structures for the TS related to $\mathrm{C}_{1}$ carbene complex formation $(\mathbf{1 6}, \mathbf{1 8}, \mathbf{2 0})$. 


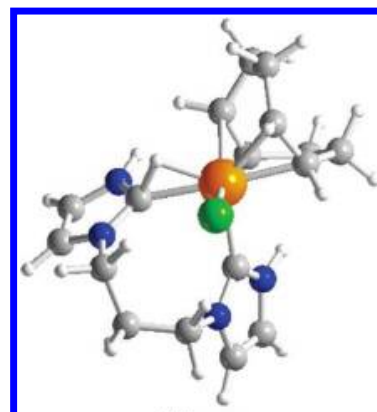

TS $_{15 \rightarrow 17}$

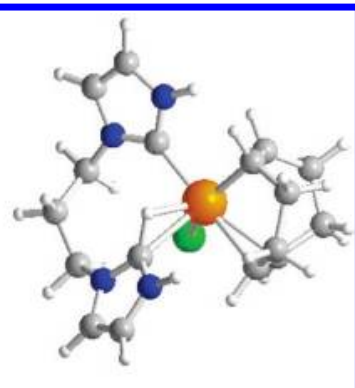

$\mathbf{T S}_{15 \rightarrow 19}$

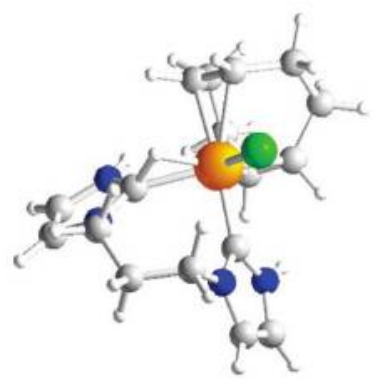

$\mathrm{TS}_{15-21}$

Figure 11. Optimized structures for the TS related to $C_{3}$ carbene complex formation $(\mathbf{1 7}, \mathbf{1 9}, \mathbf{2 1})$.

Scheme 12

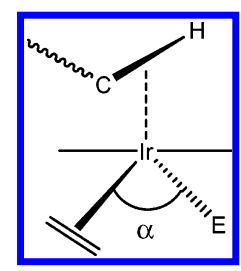

Scheme 13

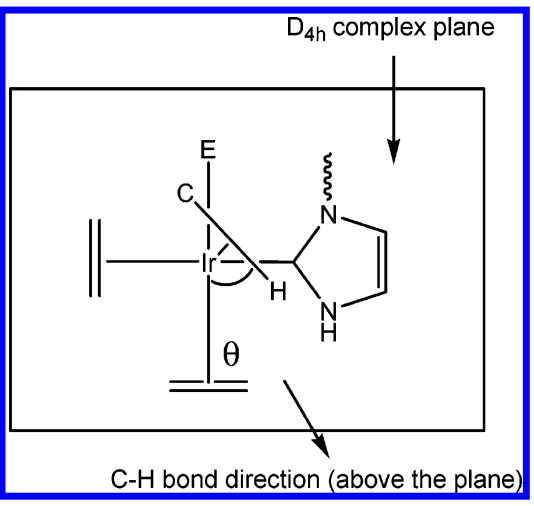

coordination plane (probably the final orientation minimizes the steric hindrance).

In our case, the favorite direction is the "olefin $-\mathrm{Ir}-\mathrm{Cl}$ " rather than the "olefin- $\mathrm{Ir}-$ carbene". $\mathrm{C}-\mathrm{H}$ orientation along that plane gives rise to complexes 18-21, which are the "low-energybarrier" ones. Alignment along the other diagonal (i.e., the "olefin-Ir-carbene") gives higher barriers, leading to complexes 16 and 17 . The ca. $3 \mathrm{kcal} / \mathrm{mol}$ energy difference between $\mathbf{T S}_{\mathbf{1 4} \rightarrow \mathbf{1 8}}$ and $\mathbf{T S}_{\mathbf{1 4 \rightarrow 2 0}}$ (or the equivalent $\mathbf{T S}_{\mathbf{1 5} \rightarrow \mathbf{1 9}}$ and $\mathbf{T S}_{\mathbf{1 5} \rightarrow \mathbf{2 1}}$ ) arises from the different orientation in space of the $\mathrm{C}-\mathrm{H}$ bond with respect to the ethene- $\mathrm{Ir}-\mathrm{Cl}$ direction (Scheme 14). The lowest energy transition state corresponds to a shorter $\mathrm{H}-$ - $-\mathrm{Cl}$ distance (around $3 \AA$ ), which permits an additional stabilizing $\mathrm{H}-\mathrm{Cl}$ interaction, found for $\mathbf{T S}_{\mathbf{1 4} \rightarrow \mathbf{1 8}}$ and $\mathbf{T} \mathbf{S}_{\mathbf{1 5} \rightarrow \mathbf{1 9}}$. On the other hand, in $\mathbf{T S}_{\mathbf{1 4 \rightarrow 2 0}}$ or $\mathbf{T} \mathbf{S}_{\mathbf{1 5} \rightarrow \mathbf{2 1}}$ the hydrogen and the chlorine atoms
Scheme 14

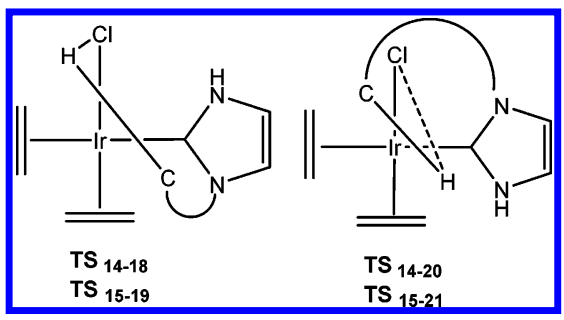

Scheme 15

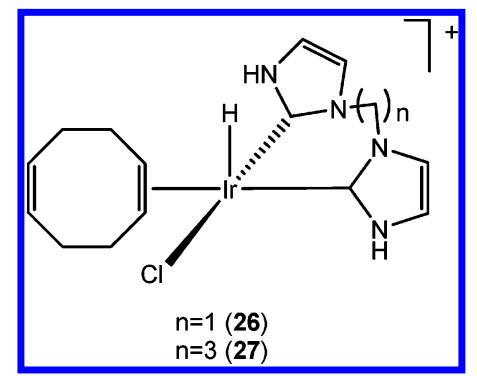

are too far apart to interact $[d(\mathrm{H}-\mathrm{Cl})$ around $4 \AA$ ㄱ. The same kind of $\mathrm{H}-\mathrm{Cl}$ "attraction" that influences the $\mathrm{C}-\mathrm{H}$ bond orientation was also observed by Hawkes et al. in the addition of azolium salts to the Wilkinson's catalyst, ${ }^{15}$ with formation of a van der Waals adduct with a strong hydrogen bond between the $\mathrm{C}(2)-\mathrm{H}$ of 1,3-dimethyl imidazolium and the chloride substituent of $\mathrm{RhCl}\left(\mathrm{PH}_{3}\right)_{3}$.

As far as the model system is concerned, the TSs found, together with their main structural parameters, are collected in Table 3.

Table 3. TSs of the Model System cis-Ir(ethene $)_{2}\left(\mathrm{CH}_{2}\right)(\mathrm{Cl})+$ $\mathrm{CH}_{4}$ (refer to Scheme 11)

\begin{tabular}{lcccccr}
\hline & $\begin{array}{c}\Delta E^{\#} \\
(\mathrm{kcal} / \mathrm{mol})\end{array}$ & $\begin{array}{c}d(\mathrm{Ir}-\mathrm{H}) \\
(\AA)\end{array}$ & $\begin{array}{c}d(\mathrm{Ir}-\mathrm{C}) \\
(\AA)\end{array}$ & $\begin{array}{c}d(\mathrm{C}-\mathrm{H}) \\
(\AA)\end{array}$ & $\begin{array}{c}\alpha \\
(\mathrm{deg})\end{array}$ & $\begin{array}{c}\theta \\
(\mathrm{deg})\end{array}$ \\
\hline $\mathbf{T S}_{22}$ & 43.7 & 1.658 & 2.318 & 1.461 & 103.3 & 14.6 \\
$\mathbf{T S}_{\mathbf{2 5}}$ & 34.5 & 1.626 & 2.273 & 1.564 & 107.0 & 18.7 \\
$\mathbf{T S}_{28}$ & 31.1 & 1.593 & 2.164 & 1.634 & & 7.2
\end{tabular}

Unfortunately, the transition states for formation of $\mathbf{2 3}$ and 24 were not found, the latter always leading to olefin loss and five-coordinated complexes $\left(\mathbf{T S}_{\mathbf{2 8}}\right.$, vide infra). All the attempts to find a TS for $\mathbf{2 3}$ led to that corresponding to hydrogenation of one coordinated olefin rather than $\mathrm{H}_{3} \mathrm{C}-\mathrm{H}$ oxidative addition. Again, as seen for the thermodynamics, there are analogies to the $\mathrm{C}_{3}$ system: the five-coordinated complex shows a lower barrier than the trans isomer, while formation of $\mathbf{2 2}$ can be definitely ruled out, since the related TS lies quite high in energy.

It is noteworthy that a more accurate exploration of the potential energy surface, while searching for the TS for formation of $\mathbf{1 8}$ and 19, showed progressive loss of coordination of the olefin trans to the hydride. The transition states found in these cases have a coordination number of one unit smaller. If these geometries are let to relax and optimize as minima, new geometries are found, with coordination number five (Scheme 15).

In the case of 26, this "new" intermediate seems to be very unstable if compared to the other products with coordination number six $(\Delta E(\mathbf{1 4}-\mathbf{2 6})=13.1 \mathrm{kcal} / \mathrm{mol})$. Besides that, it also has a much higher barrier for its formation $\left(\Delta E^{\#}=43.7 \mathrm{kcal} /\right.$ mol). The $\mathrm{C}_{3}$ case is more interesting, because the energy of 27 is very similar to that of $\mathbf{1 9}(\Delta E(\mathbf{1 5}-\mathbf{2 7})=10.1 \mathrm{kcal} / \mathrm{mol}$, $\Delta E(\mathbf{1 9}-27)=1.0 \mathrm{kcal} / \mathrm{mol})$, and its barrier is surprisingly 
Scheme 16

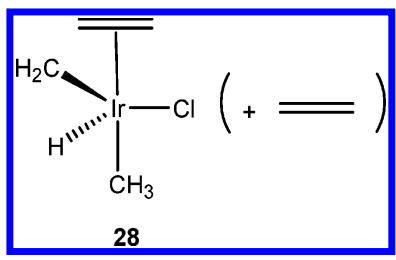

Scheme 17

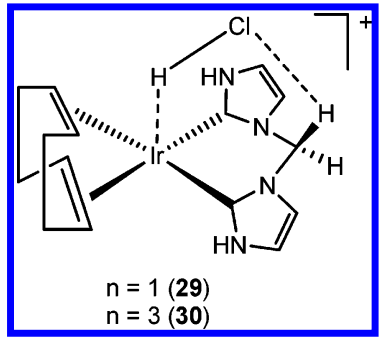

smaller than that of the trans isomer $21\left(\Delta E^{\#}=40.8 \mathrm{kcal} /\right.$ $\mathrm{mol})$. Therefore, for the longer linker $\left(\mathrm{C}_{3}\right)$, it could be an additional option that the reaction proceeds via five-coordinated intermediates, by "temporarily losing" one coordinated olefin and eventually "recoordinating" it in the end. The same behavior was also observed for the model reaction of Scheme 11. Complex 28 (Scheme 16) is formed from relaxation of the related five-coordinated TS (originated during the TS search for formation of 24). Its energy is high if compared to the more stable $25(\Delta E(\mathbf{2 8}-\mathbf{2 5})=3.2 \mathrm{kcal} / \mathrm{mol})$, but the related TS lies below that of $\mathbf{2 5}\left(\Delta E^{\sharp}(\mathbf{2 8})=31.1 \mathrm{kcal} / \mathrm{mol}\right.$, while $\Delta E^{\sharp}(\mathbf{2 5})=$ $34.5 \mathrm{kcal} / \mathrm{mol}$ ). The situation is analogous to that found in the $\mathrm{C}_{3}$ case, but here the coordination-decoordination process is not reversible, since the two olefin moieties are not linked.

(3) HCl Elimination from cis-(H,Cl) Complexes. After formation of the octahedral products 16-21, a second step of $\mathrm{HCl}$ elimination was studied, assuming that only the cis- $(\mathrm{H}, \mathrm{Cl})$ species could reductively eliminate hydrochloric acid, due to chloride and hydride proximity. In particular, the most stable cis- $(\mathrm{H}, \mathrm{Cl})$ octahedral isomer for both the $\mathrm{C}_{1}$ and the $\mathrm{C}_{3}$ cases was taken into account only (complexes 18 and 19), since the energies required to form the others (16 and 17) are too high. The elimination products are not the isolated $\mathrm{HCl}$ /square-planar species; a stable adduct is formed, with hydrogen bonding between the acid and the complex (Scheme 17).

Table 4 collects the most relevant structural data for the two TSs related to formation of $\mathbf{2 9}$ and $\mathbf{3 0}$, and Figures 12 and 13 collect their structures, together with those of the hydrogenbonded adducts.

In the $\mathrm{C}_{1}$ case, the TS for formation of 29 lies $28.2 \mathrm{kcal} / \mathrm{mol}$ above 18, and the final adduct lies $1.5 \mathrm{kcal} / \mathrm{mol}$ above 18 . One of the hydrogen atoms of the $\mathrm{CH}_{2}$ carbene spacer is forming a hydrogen bond with the chlorine atom $[d(\mathrm{HCH}---\mathrm{Cl})=2.6$ $\AA]$, and the $\mathrm{HCl}$ molecule is "bent" over iridium $[\alpha(\mathrm{Ir}-\mathrm{H}-\mathrm{Cl})$ $\left.=175^{\circ}\right]$. The $\mathrm{Ir}-\mathrm{Cl}$ bond breaks more quickly than the $\mathrm{Ir}-\mathrm{H}$ one, thus producing the final structure, with a residual $\mathrm{Ir}-\mathrm{H}$ interaction $[d(\mathrm{Ir}-\mathrm{H})=2.0 \AA]$. As a consequence, the hydrogenbonded adduct is much more stable than the isolated $\mathrm{HCl} /$ complex pair, lying $11.0 \mathrm{kcal} / \mathrm{mol}$ below the latter. The $\mathrm{C}_{3}$ case is analogous: the barrier for formation of the hydrogen-bonded

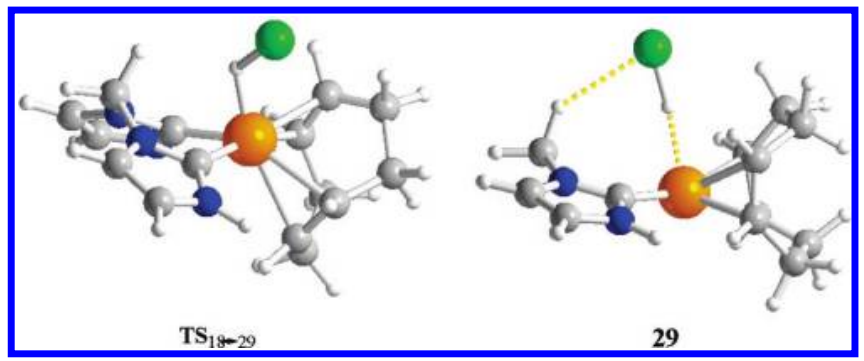

Figure 12. Transition state of $\mathrm{HCl}$ elimination from the $\mathrm{C}_{1}$ complex 18 and related product 29.

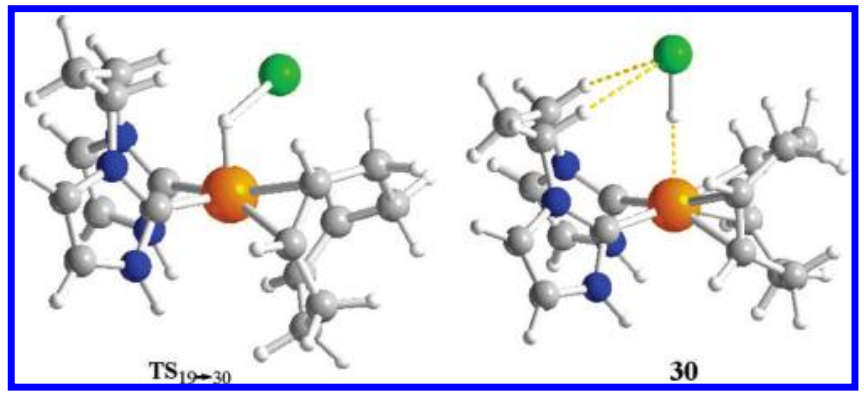

Figure 13. Transition state for $\mathrm{HCl}$ elimination from $\mathrm{C}_{3}$ complex 19 and related product 30.

adduct 30 is $24 \mathrm{kcal} / \mathrm{mol}$ and lies $0.5 \mathrm{kcal} / \mathrm{mol}$ below isolated 19. Hydrogen bonding of the same type is observed with two $\mathrm{CH}_{2}$ spacers of the $\mathrm{C}_{3}$ linker at the same time; nevertheless, the extra stabilization is lower than the previous case. 30 lies only $2 \mathrm{kcal} / \mathrm{mol}$ below the isolated $\mathrm{HCl} /$ complex pair.

An alternative pathway to the two-step mechanism $(\mathrm{C}(2)-\mathrm{H}$ oxidative addition $+\mathrm{HCl}$ elimination) for formation of complex $\mathbf{2 9}$ or $\mathbf{3 0}$ could be a direct, one-step internal $\mathrm{HCl}$ elimination, from species $\mathbf{1 4}$ or $\mathbf{1 5}$, respectively. Inspection of the geometries of the starting compounds $\mathbf{1 4}$ and $\mathbf{1 5}$ reveals the presence of a $\mathrm{C}(2)-\mathrm{H} \cdots \mathrm{Cl}$ interaction in both complexes, as proved by the short $\mathrm{C}(2)-\mathrm{H} \cdots \mathrm{Cl}$ distances found $(2.17$ and $2.24 \AA$ in $\mathbf{1 4}$ and 15, respectively). An internal deprotonation of the pending imidazolium in $\mathbf{1 4}$ and $\mathbf{1 5}$ could be envisaged with $\mathrm{Cl}$ acting as an internal base. Examination of the related energy profiles though showed that there is no formation of the square planar chelating-carbene complex. The energy monotonically increases when shortening the $\mathrm{H} \cdots \mathrm{Cl}$ distance. The conformation of both the $\mathrm{C}_{1}$ and the $\mathrm{C}_{3}$ ligands is such that it is not possible to have a proper orientation of the interacting groups in space.

\section{Conclusions}

As we have previously described, the metalation of the bisimidazolium salts to $\mathrm{Rh}^{11}$ and $\mathrm{Ir}$ (this paper) gives different products depending on the length of the linker of the two imidazolium rings. As a preliminary interpretation of this behavior, we proposed that the different relative orientation of the azole rings depending on the length of the linker may determine the steric hidrance on the $z$ axis of the molecule, thus determining whether axial ligands could occupy these positions favoring the oxidation to the pseudooctahedral M(III) species. ${ }^{11}$ In this sense, long linkers $(n=2-4)$ would facilitate the orientation of the bulky azole planes toward the empty positions

Table 4. Structural Parameters for $\mathrm{TS}_{18 \rightarrow 29}$ and $\mathrm{TS}_{19 \rightarrow 30}$

\begin{tabular}{|c|c|c|c|c|c|c|}
\hline & $\begin{array}{c}\Delta E^{\#} \\
(\mathrm{kcal} / \mathrm{mol})\end{array}$ & $\begin{array}{c}d(\mathrm{Ir}-\mathrm{H}) \\
(\AA)\end{array}$ & $\begin{array}{c}d(\mathrm{Ir}-\mathrm{Cl}) \\
(\AA)\end{array}$ & $\begin{array}{c}d(\mathrm{H}-\mathrm{Cl}) \\
(\AA)\end{array}$ & $\begin{array}{c}\alpha(\mathrm{Ir}-\mathrm{H}-\mathrm{Cl}) \\
(\mathrm{deg})\end{array}$ & $\begin{array}{c}d(\mathrm{Cl}---\mathrm{HCH}) \\
(\AA)\end{array}$ \\
\hline $\mathrm{TS}_{18 \rightarrow 29}$ & 28.2 & 1.647 & 2.874 & 1.741 & 116.0 & 3.120 \\
\hline $\mathbf{T S}_{19 \rightarrow 30}$ & 24.0 & 1.559 & 2.924 & 2.072 & 106.4 & 3.037 (mean) \\
\hline
\end{tabular}




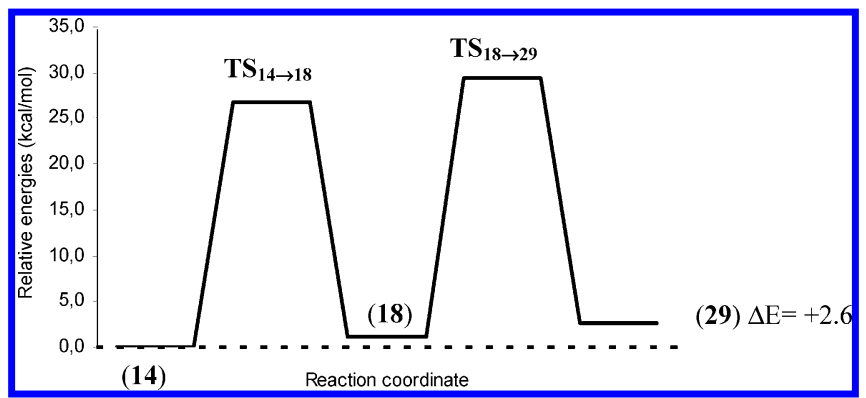

Figure 14. Global energy profile for $\mathrm{C}-\mathrm{H}$ addition on starting material 14 and the following $\mathrm{H}-\mathrm{Cl}$ elimination from cis octahedral complex 18. The final product is the hydrogen-bonded adduct 29. Since $\mathbf{T S}_{\mathbf{1 4} \rightarrow \mathbf{1 8}}$ lies lower in energy than $\mathbf{T} \mathbf{S}_{\mathbf{1 8} \rightarrow \mathbf{2 9}}$, the rate-determining step is the acid elimination, and the overall barrier to go from 14 to 29 is $29.3 \mathrm{kcal} / \mathrm{mol}$.

in the $\pm z$ axis, sterically preventing ligands from occupying the axial coordination sites. Short linkers $(n=1)$ would force the azole bulky planes into more or less close contact with the sterically crowded plane of the molecule, minimizing the sterical hindrance on the $\pm z$ axis and thus allowing the formation of pseudooctahedral M(III) species. We now see that metalation of methylenebis(methylimidazolium) hexafluorophosphate to $[(\mathrm{COD}) \mathrm{MCl}]_{2}(\mathrm{M}=\mathrm{Rh}$ and $\mathrm{Ir})$ leads to pseudooctahedral NHC$\mathrm{M}^{\mathrm{III}}$-hydride complexes. The formation of the hydride suggests that the imizadolium salt has oxidatively added to the metal, thus challenging the idea that the addition of the base is necessary for the metalation to occur. We recently reported that the role of the weak base in these systems may be different from the more general accepted role of deprotonating the imidazolium salt prior to the NHC formation. ${ }^{12}$ The experimental and theoretical results that we have presented in this paper help to analyze the mechanism of the metalation of imidazolium salts to $\operatorname{Ir}(\mathrm{I})$ complexes, as well as to clarify the role of the base and the preference in the formation of $\operatorname{Ir}(\mathrm{I})$ or $\operatorname{Ir}(\mathrm{III})$ bis-NHC complexes as final reaction products.

In the first stage of the theoretical approach, we considerered that the metalation of the bisimidazolium salts may proceed by deprotonation by the base or oxidative addition of the $\mathrm{C}-\mathrm{H}$ bond, so we compared the energetics of both processes. The first metalation process provides a series of mono-NHC-Ir(I) complexes in which one imidazolium branch remains unbound (experimental complexes 1, 3, 4, 5; theoretical 14 and 15). In the formation of the monometalated NHC-iridium complexes, both processes seem to be thermodynamically feasible, so we cannot discard either from an energetic point of view. The oxidative addition reaction rather than deprotonation with a base seems to be the most feasible process for the second metalation step, leading to a variety of complexes, whose relative stabilities were examined and rationalized on the basis of the data available. To account for the observed experimental selectivities for formation of either trans- $(\mathrm{H}, \mathrm{Cl})$ octahedral or "HCl-free"/ square-planar products (for the $\mathrm{C}_{1}$ and $\mathrm{C}_{3}$ cases, respectively), a combined $\mathrm{C}-\mathrm{H}$ addition $+\mathrm{H}-\mathrm{Cl}$ elimination path must be considered for the cis octahedral complexes. Figures 14 and 15 schematize this issue.

For the $\mathrm{C}_{1}$ case, the control of the final product is mainly thermodynamic, since the barriers to overcome the formation of the trans- $(\mathrm{H}, \mathrm{Cl})$ complex $\mathbf{2 0}$ or the adduct $\mathbf{2 9}$ are similar. In fact, in this case $\mathrm{HCl}$ elimination rather than $\mathrm{C}-\mathrm{H}$ addition is the rate-determining step, and if we assume that $\mathbf{2 9}$ is forming from the cis species $\mathbf{1 8}$, which lies $1.1 \mathrm{kcal} / \mathrm{mol}$ above $\mathbf{1 4}$, the effective barrier for its formation from 14 is $29.3 \mathrm{kcal} / \mathrm{mol}$, while that of $\mathbf{2 0}$ is $29.5 \mathrm{kcal} / \mathrm{mol}$. The trans complex though is much

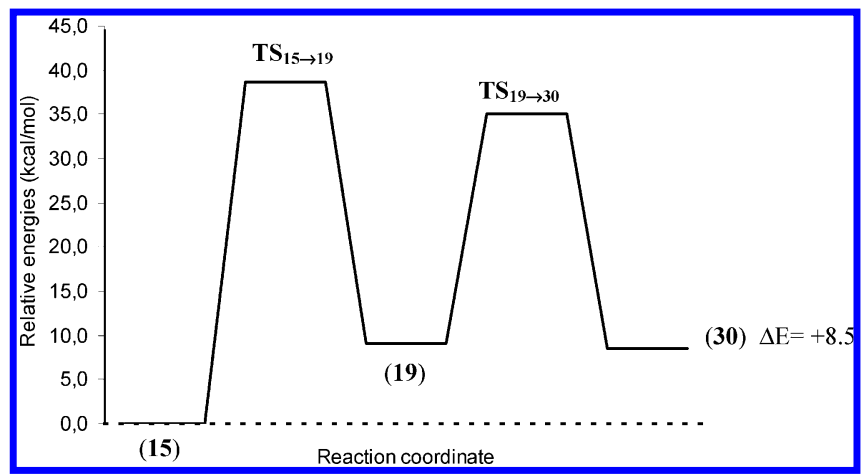

Figure 15. Global energy profile for $\mathrm{C}-\mathrm{H}$ addition on starting material 15 and the following $\mathrm{H}-\mathrm{Cl}$ elimination from cis octahedral complex 19. The final product is the hydrogen-bonded adduct $\mathbf{3 0 .}$ Since $\mathbf{T S}_{\mathbf{1 5} \rightarrow \mathbf{1 9}}$ is higher in energy than $\mathbf{T S}_{\mathbf{1 9} \rightarrow \mathbf{3 0}}$, the $\mathrm{C}-\mathrm{H}$ addition is the rate-determining step, and the overall barrier to go from $\mathbf{1 5}$ to 30 is coincident with that coming from $\mathbf{T S}_{\mathbf{1 5} \rightarrow \mathbf{1 9}}(38.7 \mathrm{kcal} / \mathrm{mol})$.

more stable than the cis one, and its formation is highly exothermic. Therefore the former is actually preferred.

In the $\mathrm{C}_{3}$ case, the control seems to be kinetic, since the barriers are not identical. $\mathrm{C}-\mathrm{H}$ addition rather than $\mathrm{HCl}$ elimination is the rate-determining step, and the TS for formation of the cis complex 19 lies ca. $3 \mathrm{kcal} / \mathrm{mol}$ lower than that of trans complex 21. As a consequence, the $c$ is isomer is kinetically preferred and can readily eliminate $\mathrm{HCl}$ to form the (observed) square planar bis(NHC)-Ir(I) species.

With our results we have demonstrated that a unified mechanism can apply to the formation of bis(NHC)- $\operatorname{Ir}(\mathrm{III})-\mathrm{H}$ and bis(NHC)-Ir(I) complexes, based on the oxidative addition of the imidazolium $\mathrm{C}-\mathrm{H}$ bonds to the metal. As pointed out in our previously reported work, ${ }^{12}$ these results would be supporting the idea that under the circumstances depicted above the weak base can play the role of an $\mathrm{HCl}$ reductive elimination inductor, rather than a deprotonating agent. We believe that these observations may bring important implications in further research in NHC-M formation.

\section{Experimental Section}

General Procedures. NMR spectra were recorded on Varian Innova 300 and $500 \mathrm{MHz}$ instruments, using $\mathrm{CDCl}_{3}, \mathrm{DMSO}-d_{6}$, and acetone- $d_{6}$ as solvents. Elemental analyses were carried out in an EA 1108 CHNS-O Carlo Erba analyzer. Electrospray mass spectra (ESI-MS) were recorded on a Micromass Quatro LC instrument using $\mathrm{CH}_{3} \mathrm{OH}$ as the mobile phase solvent, and nitrogen was employed as drying and nebulizing gas. The bromide bis $(N-$ $n$-butylimidazolium) salts, ${ }^{11}$ the biscarbene ligand precursors methylenebis $(N$-methylimidazolium $)$ chloride and ethylenebis $(N$ methylimidazolium) chloride, ${ }^{9,21}$ and $\left[(\mathrm{COD}) \mathrm{IrCl}_{2}{ }_{2}{ }^{22}\right.$ were obtained according to literature methods. All the bis(imidazolium) salts were transformed into the $\mathrm{PF}_{6}{ }^{-}$derivatives by changing the counterion using $\mathrm{NH}_{4} \mathrm{PF}_{6}$ in refluxing methanol. All the other reagents are commercially available and were used as received.

Synthesis of Methylene $((N$-methyl)imidazolium $)((N$-methyl $)$ imidazole-2-ylidene)chloro(cyclooctadiene)rhodium(I) Hexafluorophosphate, $\mathbf{1 R h}$. A mixture of $[(\mathrm{COD}) \mathrm{RhCl}]_{2}(100 \mathrm{mg}, 0.2$ mmol), methylenebis $(N$-methylimidazolium) hexafluorophosphate (190 mg, $0.4 \mathrm{mmol})$, and $\mathrm{NEt}_{3}(225 \mu \mathrm{L}, 1.6 \mathrm{mmol})$ was stirred in $\mathrm{CH}_{3} \mathrm{CN}(15 \mathrm{~mL})$ at room temperature for $15 \mathrm{~min}$. After removing the solvent under vacuum, the crude solid was purified by column

(21) (a) Albrecht, M.; Crabtree, R. H.; Mata, J.; Peris, E. Chem. Commun 2002, 32. (b) Herrmann, W. A.; Elison, M.; Fischer, J.; Kocher, C.; Artus, G. R. J. Chem.-Eur. J. 1996, 2, 772.

(22) Lin, Y.; Nomiya, K.; Finke, R. G. Inorg. Chem. 1993, 32, 6040. 
chromatography. Elution with dichloromethane separated a minor band containing $[(\mathrm{COD}) \mathrm{RhCl}]_{2}$. Further elution with a mixture of dichloromethane/acetone (8:2) afforded the separation of a yellow band that contains $\mathbf{1 R h}$ (yield $45 \%$ ). ${ }^{1} \mathrm{H}$ NMR (acetone- $d_{6}, 300$ $\mathrm{MHz}): \delta 9.47(\mathrm{~s}, 1 \mathrm{H}, \mathrm{NCHN}), 8.14\left(\mathrm{~s}, 1 \mathrm{H}\right.$, free $\left.\mathrm{CH}_{\text {imid }}\right), 7.61(\mathrm{~s}$, $1 \mathrm{H}$, free $\left.\mathrm{CH}_{\text {imid }}\right), 7.45\left(\mathrm{~d},{ }^{3} J_{\mathrm{H}-\mathrm{H}}=1.8 \mathrm{~Hz}, 1 \mathrm{H}\right.$, coord. $\left.\mathrm{CH}_{\text {imid }}\right), 7.26$ $\left(\mathrm{d},{ }^{3} J_{\mathrm{H}-\mathrm{H}}=1.8 \mathrm{~Hz}, 1 \mathrm{H}\right.$, coord. $\left.\mathrm{CH}_{\text {imid }}\right), 7.39\left(\mathrm{~d},{ }^{2} J_{\mathrm{H}-\mathrm{H}}=13.8 \mathrm{~Hz}\right.$, $1 \mathrm{H}, \mathrm{CH}_{2}$ linker $), 6.60\left(\mathrm{~d},{ }^{2} J_{\mathrm{H}-\mathrm{H}}=13.8 \mathrm{~Hz}, 1 \mathrm{H}, \mathrm{CH}_{2}\right.$ linker $), 5.05,4.92$ (m, $\left.4 \mathrm{H}, \mathrm{CH}_{\mathrm{COD}}\right), 4.10\left(\mathrm{~s}, 3 \mathrm{H}\right.$, free $\left.\mathrm{CH}_{3}\right), 3.98$ (s, 3H, coord. $\left.\mathrm{CH}_{3}\right)$, $2.40\left(\mathrm{~m}, 8 \mathrm{H}, \mathrm{CH}_{2 \mathrm{COD}}\right) .{ }^{13} \mathrm{C}$ NMR (acetone- $\left.d_{6}, 300 \mathrm{MHz}\right): \delta 185.8$ $\left(\mathrm{d},{ }^{1} J_{\mathrm{Rh}-\mathrm{C}}=51.4 \mathrm{~Hz}, \mathrm{C}-\mathrm{Rh}\right), 137.88(\mathrm{NCHN}), 124.86,124.32$ (free $\mathrm{CH}_{\text {imid }}$ ), 122.06, 121.16 (coord. $\mathrm{CH}_{\text {imid }}$ ), 99.92, 99.38, 69.81, $69.17\left(\mathrm{~d},{ }^{1} J_{\mathrm{Rh}-\mathrm{C}}=13.8 \mathrm{~Hz}, \mathrm{CH}_{\mathrm{COD}}\right), 61.83\left(\mathrm{CH}_{2}\right.$ linker $), 37.64,36.15$, 33.13, $32.4\left(\mathrm{CH}_{2 \mathrm{COD}}\right), 29.82$ (free $\left.\mathrm{CH}_{3}\right), 28.79$ (coord. $\left.\mathrm{CH}_{3}\right)$. Electrospray MS, cone $30 \mathrm{~V}, \mathrm{~m} / z$ (fragment): $490\left[\mathrm{M}+\mathrm{Na}^{+}\right.$. Anal. Calcd for $\mathrm{C}_{17} \mathrm{H}_{25} \mathrm{ClF}_{6} \mathrm{~N}_{4} \mathrm{PRh}$ (568.73): C, 35.90; H, 4.43; N, 9.85. Found: C, 35.95; H, 4.40; N, 9.96 .

Synthesis of Methylene $((N$-methyl)imidazolium $)((N$-methyl $)-$ imidazole-2-ylidene)chloro(cyclooctadiene)iridium(I) Hexafluorophosphate, 1Ir. A mixture of $[(\mathrm{COD}) \mathrm{IrCl}]_{2}(10 \mathrm{mg}, 0.015$ $\mathrm{mmol})$, methylenebis( $N$-methylimidazolium) hexafluorophosphate (16 mg, $0.03 \mathrm{mmol})$, and $\mathrm{NEt}_{3}(10 \mu \mathrm{L}, 0.07 \mathrm{mmol})$ was introduced in a NMR tube, and the evolution of the reaction was monitorized by ${ }^{1} \mathrm{H}$ NMR. After a few minutes, monometalated compound $\mathbf{1} \mathbf{I r}$ can be observed. Attempts to isolate compound $\mathbf{1 I r}$ were unsuccessful due to its tendency to evolve to the oxidative addition product (2Ir). In all cases, a mixture of $\mathbf{1 I r}$ and $\mathbf{2 I r}$ was obtained. ${ }^{1} \mathrm{H}$ NMR (DMSO- $\left.d_{6}, 300 \mathrm{MHz}\right): \delta 9.32(\mathrm{~s}, 1 \mathrm{H}, \mathrm{NCHN}), 7.89(\mathrm{~d}$, $1 \mathrm{H},{ }^{3} J_{\mathrm{H}-\mathrm{H}}=1.2 \mathrm{~Hz}$, free $\left.\mathrm{CH}_{\mathrm{imid}}\right), 7.69\left(\mathrm{~d}, 1 \mathrm{H},{ }^{3} J_{\mathrm{H}-\mathrm{H}}=1.2 \mathrm{~Hz}\right.$, free $\mathrm{CH}_{\text {imid }}$ ), 7.57 (s, $2 \mathrm{H}$, coord. $\left.\mathrm{CH}_{\text {imid }}\right), 6.74\left(\mathrm{~d},{ }^{2} J_{\mathrm{H}-\mathrm{H}}=13.8\right.$ $\mathrm{Hz}, 1 \mathrm{H}, \mathrm{CH}_{2}$ linker $), 6.52\left(\mathrm{~d},{ }^{2} J_{\mathrm{H}-\mathrm{H}}=13.2 \mathrm{~Hz}, 1 \mathrm{H}, \mathrm{CH}_{2}\right.$ linker $), 4.54$, $4.36\left(\mathrm{~m}, 4 \mathrm{H}, \mathrm{CH}_{\mathrm{COD}}\right), 3.87$ (s, 3H, free $\left.\mathrm{CH}_{3}\right), 3.83$ (s, 3H, coord. $\mathrm{CH}_{3}$ ), 2.23, 1.96 (m, 4H, $\left.\mathrm{CH}_{2 \mathrm{COD}}\right) .{ }^{13} \mathrm{C}$ NMR (DMSO- $d_{6}, 300$ $\mathrm{MHz}): \delta 181.89(\mathrm{C}-\mathrm{Ir}), 137.93(\mathrm{NCHN}), 124.81,124.57$ (free $\mathrm{CH}_{\text {imid }}$ ), 121.85, 121.68 (coord. $\mathrm{CH}_{\text {imid }}$ ), 85.77, 84.79, 53.17, 52.14 $\left(\mathrm{CH}_{\mathrm{COD}}\right), 67.26\left(\mathrm{CH}_{2}\right.$ linker $), 38.09,37.94,36.86,36.62\left(\mathrm{CH}_{2 \mathrm{COD}}\right)$, 30.26 (free $\mathrm{CH}_{3}$ ), 29.04 (coord. $\mathrm{CH}_{3}$ ).

Synthesis of Methylenebis( $(N$-methyl)imidazole-2-ylidene)chloro(cyclooctadiene)(hydride)iridium(III) Hexafluorophosphate, 2Ir. A mixture of $[(\mathrm{COD}) \mathrm{IrCl}]_{2}(200 \mathrm{mg}, 0.3 \mathrm{mmol})$, methylenebis $(N$-methylimidazolium) hexafluorophosphate $(280 \mathrm{mg}$, $0.6 \mathrm{mmol})$, and $\mathrm{NEt}_{3}(225 \mu \mathrm{L}, 1.6 \mathrm{mmol})$ was stirred under inert conditions in $\mathrm{CH}_{3} \mathrm{CN}(15 \mathrm{~mL})$ at $40{ }^{\circ} \mathrm{C}$ for $1 \mathrm{~h}$. After cooling and removing the solvent, the crude solid was washed with dichloromethane, giving the desired product as a pale yellow solid (yield $40 \%) .{ }^{1} \mathrm{H}$ NMR (acetone- $\left.d_{6}, 300 \mathrm{MHz}\right): \delta 7.56\left(\mathrm{~d},{ }^{3} J_{\mathrm{H}-\mathrm{H}}=1.8\right.$ $\left.\mathrm{Hz}, 2 \mathrm{H}, \mathrm{CH}_{\text {imid }}\right), 7.29\left(\mathrm{~d},{ }^{3} \mathrm{~J}_{\mathrm{H}-\mathrm{H}}=1.8 \mathrm{~Hz}, 2 \mathrm{H}, \mathrm{CH}_{\text {imid }}\right), 6.45(\mathrm{~d}$, ${ }^{2} J_{\mathrm{H}-\mathrm{H}}=13.5 \mathrm{~Hz}, 1 \mathrm{H}, \mathrm{CH}_{2}$ linker $), 6.31\left(\mathrm{~d},{ }^{2} J_{\mathrm{H}-\mathrm{H}}=13.5 \mathrm{~Hz}, 1 \mathrm{H}\right.$, $\mathrm{CH}_{2}$ linker), 5.44, $5.17\left(\mathrm{~m}, 2 \mathrm{H}, \mathrm{CH}_{\mathrm{COD}}\right), 4.14\left(\mathrm{~s}, 6 \mathrm{H}, \mathrm{CH}_{3}\right), 2.91$, 2.50 (m, 4H, $\left.\mathrm{CH}_{2} \mathrm{COD}\right),-15.64$ (Ir-hydride). ${ }^{13} \mathrm{C}$ NMR (acetone$\left.d_{6}, 300 \mathrm{MHz}\right): \delta 146.83(\mathrm{C}-\mathrm{Ir}), 124.79,120.96\left(\mathrm{CH}_{\mathrm{imid}}\right), 91.56$, $88.56\left(\mathrm{CH}_{\mathrm{COD}}\right), 64.90\left(\mathrm{CH}_{2}\right.$ linker $), 37.17,32.59\left(\mathrm{CH}_{2 \mathrm{COD}}\right), 28.61$ $\left(\mathrm{CH}_{3}\right)$. Electrospray MS, cone $30 \mathrm{~V}, \mathrm{~m} / \mathrm{z}$ (fragment): $509[\mathrm{M}]^{+}$, $477[\mathrm{M}-\mathrm{HCl}]^{+}$. Anal. Calcd for $\mathrm{C}_{17} \mathrm{H}_{25} \mathrm{ClF}_{6} \mathrm{IrN}_{4} \mathrm{P}$ (658.04): C, 31.03; H, 3.83; N, 8.51. Found: C, 30.97; H, 3.79; N, 8.63.

General Procedure to Obtain Monometalated Species 3a5a; Direct Metalation Reactions. A mixture of $[(\mathrm{COD}) \operatorname{IrCl}]_{2}(1$ equiv), the appropriate bis(imidazolium) hexafluorophosphate (2 equiv), and $\mathrm{NEt}_{3}$ (2.5 equiv) was stirred in $\mathrm{CH}_{3} \mathrm{CN}(15 \mathrm{~mL})$ at 60 ${ }^{\circ} \mathrm{C}$ for $4 \mathrm{~h}$. After cooling, the solvent was removed under vacuum. The crude solid was washed with dichloromethane to remove unreacted bis(imidazolium) salt, and the solution was concentrated under reduced pressure. Finally, the monometalated species were precipitated as pale orange solids from a mixture of $\mathrm{CH}_{2} \mathrm{Cl}_{2} / \mathrm{Et}_{2} \mathrm{O}$.

Ethylene $((N$-methyl)imidazolium $)(N$-methyl)imidazole2-ylidene)chloro(cyclooctadiene)iridium(I) Hexafluorophosphate, 3a. ${ }^{1} \mathrm{H}$ NMR (DMSO- $\left.d_{6}, 300 \mathrm{MHz}\right): \delta 9.07$ (s, $\left.1 \mathrm{H}, \mathrm{NCHN}\right)$,
7.74, 7.68 (s, $2 \mathrm{H}$, free $\mathrm{CH}_{\text {imid }}$ ), 7.26, 7.23 (s, $2 \mathrm{H}$, coord. $\mathrm{CH}_{\text {imid }}$ ), $5.93\left(\mathrm{t},{ }^{3} J_{\mathrm{H}-\mathrm{H}}=7.7 \mathrm{~Hz}, \mathrm{~N}-\mathrm{CH}_{2}-\mathrm{CH}_{2}-\mathrm{NCHN}\right), 5.84\left(\mathrm{t},{ }^{3} J_{\mathrm{H}-\mathrm{H}}=\right.$ $\left.7.2 \mathrm{~Hz}, \mathrm{~N}-\mathrm{CH}_{2}-\mathrm{CH}_{2}-\mathrm{NCHN}\right), 3.83\left(\mathrm{~s}, 3 \mathrm{H}\right.$, free $\left.\mathrm{CH}_{3}\right), 3.80(\mathrm{~s}$, $3 \mathrm{H}$, coord. $\left.\mathrm{CH}_{3}\right) \cdot{ }^{13} \mathrm{C} \mathrm{NMR}\left(\mathrm{CDCl}_{3}, 300 \mathrm{MHz}\right): \delta 179(\mathrm{C}-\mathrm{Ir})$, $136.10(\mathrm{NCHN}), 123.61,122.83\left(\right.$ free $\left.\mathrm{CH}_{\text {imid }}\right), 122.50,120.69$ (coord. $\left.\mathrm{CH}_{\text {imid }}\right), 84.44,84.22$, 49.59, $49.30\left(\mathrm{CH}_{\mathrm{COD}}\right), 37.71,36.51$ $\left(\mathrm{CH}_{2}\right.$ linker $), 34.14,33.24,30.24,29.28\left(\mathrm{CH}_{2} \mathrm{COD}\right), 27.24$ (free $\left.\mathrm{CH}_{3}\right)$, 26.72 (coord. $\mathrm{CH}_{3}$ ). Electrospray MS, cone $40 \mathrm{~V}, \mathrm{~m} / \mathrm{z}$ (fragment): $527\left[\mathrm{M}^{+}, 491[\mathrm{M}-\mathrm{HCl}]^{+}\right.$. Anal. Calcd for $\mathrm{C}_{18} \mathrm{H}_{27} \mathrm{ClF}_{6} \mathrm{IrN}_{4} \mathrm{P}$ (672.07): C, 32.17; H, 4.05; N, 8.34. Found: C, 32.15; H, 4.10; N, 8.36.

Trimethylene $((N$-methyl)imidazolium $)(N$-methyl)imidazole2-ylidene)chloro(cyclooctadiene)iridium(I) Hexafluorophosphate, 4a. ${ }^{1} \mathrm{H}$ NMR (DMSO- $\left.d_{6}, 300 \mathrm{MHz}\right): \delta 9.11(\mathrm{~s}, 1 \mathrm{H}, \mathrm{NCHN}$ ), 7.81, 7.74 (s, $2 \mathrm{H}$, free $\mathrm{CH}_{\text {imid }}$ ), 7.28, 7.26 (s, $2 \mathrm{H}$, coord. $\mathrm{CH}_{\text {imid }}$ ), $5.93\left(\mathrm{t}, 2 \mathrm{H},{ }^{3} \mathrm{~J}_{\mathrm{H}-\mathrm{H}}=7.7 \mathrm{~Hz}, \mathrm{~N}-\mathrm{CH}_{2}-\mathrm{CH}_{2}-\mathrm{CH}_{2}-\mathrm{NCHN}\right), 5.83$ (t, $\left.2 \mathrm{H},{ }^{3} \mathrm{~J}_{\mathrm{H}-\mathrm{H}}=7.5 \mathrm{~Hz}, \mathrm{~N}-\mathrm{CH}_{2}-\mathrm{CH}_{2}-\mathrm{CH}_{2}-\mathrm{NCHN}\right), 4.54(\mathrm{~m}$, $\left.2 \mathrm{H}, \mathrm{N}-\mathrm{CH}_{2}-\mathrm{CH}_{2}-\mathrm{CH}_{2}-\mathrm{NCHN}\right), 3.84\left(\mathrm{~s}, 3 \mathrm{H}\right.$, free $\left.\mathrm{CH}_{3}\right), 3.81$ (s, $3 \mathrm{H}$, coord. $\left.\mathrm{CH}_{3}\right) \cdot{ }^{13} \mathrm{C} \mathrm{NMR}\left(\mathrm{CDCl}_{3}, 300 \mathrm{MHz}\right): \delta 179(\mathrm{C}-\mathrm{Ir})$, $136.20(\mathrm{NCHN}), 123.80,123.63\left(\right.$ free $\left.\mathrm{CH}_{\text {imid }}\right), 122.90,121.76$ (coord. $\mathrm{CH}_{\text {imid }}$ ), 50.92, 43.92, $37.80\left(\mathrm{CH}_{2}\right.$ linker), 36.25 (free $\left.\mathrm{CH}_{3}\right)$, 30.26 (coord. $\mathrm{CH}_{3}$ ). Electrospray MS, cone $40 \mathrm{~V}, \mathrm{~m} / \mathrm{z}$ (fragment): $541[\mathrm{M}]^{+}, 505[\mathrm{M}-\mathrm{HCl}]^{+}$. Anal. Calcd for $\mathrm{C}_{19} \mathrm{H}_{29} \mathrm{ClF}_{6} \mathrm{IrN}_{4} \mathrm{P}$ (686.14): C, 33.26; H, 4.26; N, 8.17. Found: C, 33.20; H, 4.29; N, 8.20.

Tetramethylene $((N$-methyl)imidazolium $)(N$-methyl)imidazole2-ylidene)chloro(cyclooctadiene)iridium(I) Hexafluorophosphate, 5a. ${ }^{1} \mathrm{H}$ NMR (DMSO- $\left.d_{6}, 300 \mathrm{MHz}\right): \delta 9.00(\mathrm{~s}, 1 \mathrm{H}, \mathrm{NCHN})$, 7.61, 7.51 (s, $2 \mathrm{H}$, free $\mathrm{CH}_{\text {imid }}$ ), 7.23, 7.12 (s, 2H, coord. $\mathrm{CH}_{\text {imid }}$ ), $5.93\left(\mathrm{t}, 2 \mathrm{H},{ }^{3} \mathrm{~J}_{\mathrm{H}-\mathrm{H}}=7.7 \mathrm{~Hz}, \mathrm{~N}-\mathrm{CH}_{2}-\mathrm{CH}_{2}-\mathrm{CH}_{2}-\mathrm{CH}_{2}-\mathrm{NCHN}\right)$, $5.84\left(\mathrm{t}, 2 \mathrm{H},{ }^{3} \mathrm{~J}_{\mathrm{H}-\mathrm{H}}=7.5 \mathrm{~Hz}, \mathrm{~N}-\mathrm{CH}_{2}-\mathrm{CH}_{2}-\mathrm{CH}_{2}-\mathrm{CH}_{2}-\mathrm{NCHN}\right)$, $5.16\left(\mathrm{~m}, 4 \mathrm{H}, \mathrm{N}-\mathrm{CH}_{2}-\mathrm{CH}_{2}-\mathrm{CH}_{2}-\mathrm{CH}_{2}-\mathrm{NCHN}\right), 3.83$ (s, 3H, free $\left.\mathrm{CH}_{3}\right), 3.81$ (s, $3 \mathrm{H}$, coord. $\left.\mathrm{CH}_{3}\right) \cdot{ }^{13} \mathrm{C} \mathrm{NMR}\left(\mathrm{CDCl}_{3}, 300 \mathrm{MHz}\right): \delta$ $180.05(\mathrm{C}-\mathrm{Ir}), 136.31(\mathrm{NCHN}), 123.73,123.18\left(\right.$ free $\left.\mathrm{CH}_{\text {imid }}\right)$, 122.56, 121.97 (coord. $\mathrm{CH}_{\text {imid }}$ ), 86.13, 85.20, 50.55, $49.79\left(\mathrm{CH}_{\mathrm{COD}}\right)$, 53.67, 52.15, 49.76, 37.86 ( $\mathrm{CH}_{2}$ linker $), 36.60,34.22,33.05,31.04$ $\left(\mathrm{CH}_{2} \mathrm{COD}\right.$ ), 30.35 (free $\mathrm{CH}_{3}$ ), 28. 97 (coord. $\mathrm{CH}_{3}$ ). Electrospray MS, cone $40 \mathrm{~V}, \mathrm{~m} / \mathrm{z}$ (fragment): $555[\mathrm{M}]^{+}$. Anal. Calcd for $\mathrm{C}_{20} \mathrm{H}_{31^{-}}$ $\mathrm{ClF}_{6} \mathrm{IrN}_{4} \mathrm{P}$ (700.12): C, 34.31; H, 4.46; N, 8.00. Found: C, 34.25; $\mathrm{H}, 4.47 ; \mathrm{N}, 8.12$.

General Procedure to Obtain Doubly Metalated Species 6-8; Transmetalation Reactions. A suspension of the appropriate bis(imidazolium) salt ( 1 equiv) and silver oxide ( 2.5 equiv) was stirred at room temperature for $2 \mathrm{~h}$. Then, $[(\mathrm{COD}) \mathrm{IrCl}]_{2}(0.5$ equiv) was added to the gray solution, and the formation of a white precipitate was immediately observed. To complete the reaction, the mixture was stirred at room temperature for $3 \mathrm{~h}$. Finally, the suspension was filtered through Celite to remove unreacted silver oxide and insoluble residues as silver salts. The solution was concentrated under reduced pressure, and the crude solid was redissolved in dichloromethane and purified by gradient column chromatography using silica gel.

Synthesis of Ethylenebis( $N$-methylimidazol-2-ylidene)(cyclooctadiene)iridium(I) Hexafluorophosphate, 6a. The reaction was carried out at room temperature in methanol $(20 \mathrm{~mL})$, with ethylenebis $(N$-methylimidazolium) dichloride $(78 \mathrm{mg}, 0.30 \mathrm{mmol})$, $\mathrm{Ag}_{2} \mathrm{O}$ (173.8 mg, $\left.0.75 \mathrm{mmol}\right)$, and $\left[(\mathrm{COD}) \mathrm{IrCl}_{2}(100 \mathrm{mg}, 0.15\right.$ mmol). Elution with a gradient of $\mathrm{CH}_{2} \mathrm{Cl}_{2}$ /acetone (1:1) and $\mathrm{KPF}_{6}$ afforded the separation of $\mathbf{6 a}$ as an orange band. Compound $\mathbf{6 a}$ was recrystallized from $\mathrm{CH}_{2} \mathrm{Cl}_{2} / \mathrm{Et}_{2} \mathrm{O}$ as an orange crystalline solid (yield 7\%). ${ }^{1} \mathrm{H}$ NMR $\left(\mathrm{CDCl}_{3}, 300 \mathrm{MHz}\right): \delta 7.47\left(\mathrm{~d}, 2 \mathrm{H}, \mathrm{CH}_{\mathrm{imid}}\right)$, $6.78\left(\mathrm{~d}, 2 \mathrm{H}, \mathrm{CH}_{\mathrm{imid}}\right), 5.2-5.5\left(\mathrm{~m}, 2 \mathrm{H}, \mathrm{NCH}_{2}\right.$ linker $), 4.6-5.1(\mathrm{~m}$, $\left.4 \mathrm{H}, \mathrm{CH}_{\mathrm{COD}}\right), 4.56$ (m, 2H, $\mathrm{CH}_{2}$ linker), 3.79 (s, 6H, $\left.\mathrm{CH}_{3}\right) .{ }^{13} \mathrm{C} \mathrm{NMR}$ $\left(\mathrm{CDCl}_{3}, 300 \mathrm{MHz}\right): \delta 177.59(\mathrm{C}-\mathrm{Ir}), 123.09,122.54\left(\mathrm{CH}_{\mathrm{imid}}\right)$, $76.78\left(\mathrm{CH}_{\mathrm{COD}}\right), 52.21\left(\mathrm{CH}_{2}\right.$ linker $), 34.27\left(\mathrm{CH}_{3}\right), 33.16,31.42$ $\left(\mathrm{CH}_{2 \mathrm{COD}}\right)$. Electrospray MS, cone $35 \mathrm{~V}, \mathrm{~m} / \mathrm{z}$ (fragment): 491.4 
$[\mathrm{M}]^{+}$. Anal. Calcd for $\mathrm{C}_{18} \mathrm{H}_{26} \mathrm{~F}_{6} \mathrm{IrN}_{4} \mathrm{P}$ (635.61): C, 34.01; H, 4.12; N, 8.81. Found: C, 33.97; H, 4.01; N, 8.85.

Synthesis of Ethylenebis( $N$-n-butylimidazol-2-ylidene)(cyclooctadiene)iridium(I) Hexafluorophosphate, $\mathbf{6 b}$. The reaction was carried out at room temperature in dichloromethane $(20 \mathrm{~mL})$, with ethylenebis $(N-n$-butylimidazolium) dichloride (103 mg, 0.30 $\mathrm{mmol}), \mathrm{Ag}_{2} \mathrm{O}$ (172 $\left.\mathrm{mg}, 0.74 \mathrm{mmol}\right)$, and $[(\mathrm{COD}) \mathrm{IrCl}]_{2}(100 \mathrm{mg}$, $0.15 \mathrm{mmol})$. Column chromatography involved elution with $\mathrm{CH}_{2}-$ $\mathrm{Cl}_{2}$ /acetone $(1: 1)$, and $\mathrm{KPF}_{6}$ separated compound $\mathbf{6} \mathbf{b}$ as an orange band. Compound $\mathbf{6 b}$ was recrystallized from $\mathrm{CH}_{2} \mathrm{Cl}_{2} / \mathrm{Et}_{2} \mathrm{O}$ as an orange crystalline solid (yield $63 \%) .{ }^{1} \mathrm{H} \mathrm{NMR}\left(\mathrm{CDCl}_{3}, 300 \mathrm{MHz}\right)$ : $\delta 7.04\left(\mathrm{~d},{ }^{3} J_{\mathrm{H}-\mathrm{H}}=1.8 \mathrm{~Hz}, \mathrm{CH}_{\text {imid }}\right), 6.88\left(\mathrm{~d},{ }^{3} J_{\mathrm{H}-\mathrm{H}}=1.8 \mathrm{~Hz}, \mathrm{CH}_{\text {imid }}\right)$, 5.28 (m, 2H, $\mathrm{CH}_{2}$ linker $), 4.40-4.60\left(\mathrm{~m}, 2 \mathrm{H}, \mathrm{CH}_{2}(n-\mathrm{Bu})\right), 4.20-$ 4.10 (m, 8H; $2 \mathrm{H}, \mathrm{CH}_{2}$ linker $; 4 \mathrm{H} \mathrm{CH} \mathrm{COD}_{\mathrm{COD}} ; 2 \mathrm{H}, \mathrm{CH}_{2}(n-\mathrm{Bu})$ ), 3.90$4.00\left(\mathrm{~m}, 2 \mathrm{H}, \mathrm{CH}_{2}(n-\mathrm{Bu})\right), 2.32-2.25\left(\mathrm{~m}, 4 \mathrm{H}, \mathrm{CH}_{2} \mathrm{COD}\right), 2.15-$ $2.20\left(\mathrm{~m}, 4 \mathrm{H}, \mathrm{CH}_{2} \mathrm{COD}\right), 1.83-1.85$ (m, 2H, $\left.\mathrm{CH}_{2}(n-\mathrm{Bu})\right), 1.69-$ $1.64\left(\mathrm{~m}, 2 \mathrm{H}, \mathrm{CH}_{2}(n-\mathrm{Bu})\right), 1.33-1.31\left(\mathrm{~m}, 2 \mathrm{H}, \mathrm{CH}_{2}(n-\mathrm{Bu})\right), 0.91-$ $0.95\left(\mathrm{t}, 6 \mathrm{H},{ }^{3} \mathrm{~J}_{\mathrm{H}-\mathrm{H}}=12 \mathrm{~Hz}, \mathrm{CH}_{3}\right) .{ }^{13} \mathrm{C} \mathrm{NMR}\left(\mathrm{CDCl}_{3}, 300 \mathrm{MHz}\right)$ : $\delta 174.99$ (C-Ir); 123.34, $120.73\left(\mathrm{CH}_{\text {imid }}\right), 77.29\left(\mathrm{CH}_{\mathrm{COD}}\right), 73.61$ $\left(\mathrm{CH}_{\mathrm{COD}}\right), 51.09\left(\mathrm{CH}_{2}\right.$ linker $), 47.72\left(\mathrm{CH}_{2}(n-\mathrm{Bu})\right), 33.79\left(\mathrm{CH}_{2}(n-\mathrm{Bu})\right)$, 31.57, $31.41\left(\mathrm{CH}_{2 \mathrm{COD}}\right), 20.10\left(\mathrm{CH}_{2}(n-\mathrm{Bu})\right), 13.83\left(\mathrm{CH}_{3}\right)$. Electrospray MS, cone $35 \mathrm{~V}, \mathrm{~m} / \mathrm{z}$ (fragment): $575[\mathrm{M}]^{+}$. Anal. Calcd for $\mathrm{C}_{24} \mathrm{H}_{38} \mathrm{~F}_{6} \mathrm{IrN}_{4} \mathrm{P}$ (719.77): C, 40.05; H, 5.32; N, 7.78. Found: C, 40.00; H, 5.36; N, 7.82.

Synthesis of Trimethylenebis( $N$-methylimidazol-2-ylidene)(cyclooctadiene)iridium(I) Hexafluorophosphate, 7a. The reaction was carried out at room temperature in methanol $(20 \mathrm{~mL})$, with trimethylenebis $(N$-methylimidazolium) dibromide $(109 \mathrm{mg}$, $0.30 \mathrm{mmol}), \mathrm{Ag}_{2} \mathrm{O}(172 \mathrm{mg}, 0.74 \mathrm{mmol})$, and $[(\mathrm{COD}) \mathrm{IrCl}]_{2}(100$ $\mathrm{mg}, 0.15 \mathrm{mmol})$. Column chromatography involved elution with $\mathrm{CH}_{2} \mathrm{Cl}_{2}$ /acetone $(1: 1)$, and $\mathrm{KPF}_{6}$ separated compound $\mathbf{7 a}$ as an orange band. Compound $7 \mathbf{a}$ was recrystallized from $\mathrm{CH}_{2} \mathrm{Cl}_{2} / \mathrm{Et}_{2} \mathrm{O}$ as an orange crystalline solid (yield $10 \%) .{ }^{1} \mathrm{H} \mathrm{NMR}\left(\mathrm{CDCl}_{3}, 500\right.$ $\mathrm{MHz}): \delta 6.88\left(\mathrm{~d}, 2 \mathrm{H}, \mathrm{CH}_{\text {imid }}\right), 6.82\left(\mathrm{~d}, 2 \mathrm{H}, \mathrm{CH}_{\text {imid }}\right), 4.65(\mathrm{dd}, 2 \mathrm{H}$, $\mathrm{CH}_{2}$ linker $), 4.22$ (dd, $2 \mathrm{H}, \mathrm{CH}_{2}$ linker $), 4.00$ (m, 4H, $\left.\mathrm{CH}_{\mathrm{COD}}\right), 3.78$ (s, $\left.6 \mathrm{H}, \mathrm{CH}_{3}\right), 2.38-2.45$ (m, $1 \mathrm{H}, \mathrm{CH}_{2}$ linker), 2.24-2.21 (m, 4H, $\mathrm{CH}_{2}$ COD), 2.02-1.84 (m, 5H; 1H, $\mathrm{CH}_{2}$ linker; $\left.4 \mathrm{H}, \mathrm{CH}_{2} \mathrm{COD}\right) .{ }^{13} \mathrm{C} \mathrm{NMR}$ $\left(\mathrm{CDCl}_{3}, 500 \mathrm{MHz}\right): \delta 178.04(\mathrm{C}-\mathrm{Ir}), 122.66,122.45\left(\mathrm{CH}_{\text {imid }}\right)$, $77.31\left(\mathrm{CH}_{\mathrm{COD}}\right), 76.00\left(\mathrm{CH}_{\mathrm{COD}}\right), 52.43\left(\mathrm{CH}_{2 \text { linker }}\right), 37.62\left(\mathrm{CH}_{2}\right.$ linker $)$, $33.45\left(\mathrm{CH}_{3}\right), 31.42\left(\mathrm{CH}_{2} \mathrm{COD}\right)$. Electrospray MS, cone $40 \mathrm{~V}, \mathrm{~m} / \mathrm{z}$ (fragment): $505.4[\mathrm{M}]^{+}$. Anal. Calcd for $\mathrm{C}_{19} \mathrm{H}_{28} \mathrm{~F}_{6} \operatorname{IrN}_{4} \mathrm{P}$ (649.63): C, 35.13; H, 4.34; N, 8.62. Found: C, 35.10; H, 4.30; N, 8.64.

Synthesis of Trimethylenebis( $N$ - $n$-butylimidazol-2-ylidene)(cyclooctadiene)iridium(I) Hexafluorophosphate, 7b. Transmetalation was carried out at room temperature in dichloromethane with trimethylenebis $(N$ - $n$-butylimidazolium) dibromide (134 mg, 0.30 $\mathrm{mmol}), \mathrm{Ag}_{2} \mathrm{O}$ (172 $\left.\mathrm{mg}, 0.74 \mathrm{mmol}\right)$, and [(COD) $\left.\mathrm{IrCl}\right]_{2}(100 \mathrm{mg}$, $0.15 \mathrm{mmol}$ ). Column chromatography involved elution with $\mathrm{CH}_{2}$ $\mathrm{Cl}_{2}$ /acetone $(1: 1)$, and $\mathrm{KPF}_{6}$ separated compound $\mathbf{7 b}$ as an orange band. Compound $7 \mathbf{b}$ was recrystallized from $\mathrm{CH}_{2} \mathrm{Cl}_{2} /$ diethyl ether as an orange crystalline solid (yield $70 \%) .{ }^{1} \mathrm{H} \mathrm{NMR}\left(\mathrm{CDCl}_{3}, 500\right.$ $\mathrm{MHz}): \delta 6.90\left(\mathrm{~d}, 2 \mathrm{H}, \mathrm{CH}_{\mathrm{imid}}\right), 6.84\left(\mathrm{~d}, 2 \mathrm{H}, \mathrm{CH}_{\mathrm{imid}}\right), 4.66-4.61$ (m, 2H, $\mathrm{CH}_{2}$ linker), 4.38-4.32 (m, 2H, $\mathrm{CH}_{2}$ linker $), 4.24-4.20(2 \mathrm{H}$, $\left.\mathrm{CH}_{2}(n-\mathrm{Bu})\right), 3.99,3.93\left(\mathrm{~m}, 4 \mathrm{H}, \mathrm{CH}_{\mathrm{COD}}\right), 3.84-3.78\left(\mathrm{~m}, 2 \mathrm{H}, \mathrm{CH}_{2}\right.$ linker), $2.20\left(\mathrm{~m}, 4 \mathrm{H}, \mathrm{CH}_{2}\right.$ COD $), 1.80-1.90\left(\mathrm{~m}, 2 \mathrm{H}, \mathrm{CH}_{2}(n-\mathrm{Bu})\right) .{ }^{13} \mathrm{C}$ NMR $\left(\mathrm{CDCl}_{3}, 300 \mathrm{MHz}\right): \delta 177.12$ (C-Ir), 123.24, 119.99 $\left(\mathrm{CH}_{\text {imid }}\right), 77.22\left(\mathrm{CH}_{\mathrm{COD}}\right), 75.28\left(\mathrm{CH}_{\mathrm{COD}}\right), 52.54,50.52\left(\mathrm{CH}_{2}\right.$ linker $)$, $33.27\left(\mathrm{CH}_{2}(n-\mathrm{Bu})\right), 31.50,31.41\left(\mathrm{CH}_{2} \mathrm{COD}\right), 20.36\left(\mathrm{CH}_{2}(n-\mathrm{Bu})\right)$, $13.85\left(\mathrm{CH}_{3}\right)$. Electrospray MS, cone $30 \mathrm{~V}, \mathrm{~m} / \mathrm{z}$ (fragment): 589.3 $\left[\mathrm{M}^{+}\right]$. Anal. Calcd for $\mathrm{C}_{25} \mathrm{H}_{40} \mathrm{~F}_{6} \mathrm{IrN}_{4} \mathrm{P}$ (733.79): C, 40.92; H, 5.49; N, 7.64. Found: C, 40.90; H, 5.53; N, 7.60.

Synthesis of Tetramethylenebis( $N$-methylimidazol-2-ylidene)(cyclooctadiene)iridium(I) Hexafluorophosphate, 8a. Transmetalation was carried out at room temperature in methanol with tetramethylenebis $(N$ - $n$-methylimidazolium) dibromide $(113.1 \mathrm{mg}$; $0.30 \mathrm{mmol}), \mathrm{Ag}_{2} \mathrm{O}$ (172 $\left.\mathrm{mg}, 0.74 \mathrm{mmol}\right)$, and [(COD) $\left.\mathrm{IrCl}\right]_{2}(100$ $\mathrm{mg}, 0.15 \mathrm{mmol})$. Column chromatography involved elution with
$\mathrm{CH}_{2} \mathrm{Cl}_{2}$ /acetone (1:1), and $\mathrm{KPF}_{6}$ separated compound $\mathbf{8 a}$ as an orange band. Compound $\mathbf{8 a}$ was recrystallized from $\mathrm{CH}_{2} \mathrm{Cl}_{2} /$ diethyl ether as an orange crystalline solid (yield $10 \%) .{ }^{1} \mathrm{H} \mathrm{NMR}\left(\mathrm{CDCl}_{3}\right.$, $500 \mathrm{MHz}): \delta 6.90\left(\mathrm{~d}, 2 \mathrm{H}, \mathrm{CH}_{\text {imid }}\right), 6.88\left(\mathrm{~d}, 2 \mathrm{H}, \mathrm{CH}_{\text {imid }}\right), 4.87-$ 4.82 ( $\mathrm{m}, 2 \mathrm{H}, \mathrm{CH}_{2}$ linker $), 4.07-4.03\left(\mathrm{~m}, 2 \mathrm{H}, \mathrm{CH}_{2}\right.$ linker $), 3.74,3.72$ (m, 2H, $\left.\mathrm{CH}_{\mathrm{COD}}\right), 2.26-2.16\left(\mathrm{~m}, 2 \mathrm{H}, \mathrm{CH}_{2}\right.$ linker $), 1.95-1.85$ (m, 4H, $\mathrm{CH}_{2}$ linker $), 1.51\left(\mathrm{~s}, 6 \mathrm{H}, \mathrm{CH}_{3}\right) \cdot{ }^{13} \mathrm{C} \mathrm{NMR}\left(\mathrm{CDCl}_{3}, 500 \mathrm{MHz}\right): \delta$ 177.09 (C-Ir), 123.30, $120.89\left(\mathrm{CH}_{\mathrm{imid}}\right), 75.79\left(\mathrm{CH}_{\mathrm{COD}}\right), 45.69$ $\left(\mathrm{CH}_{2}\right.$ linker $), 37.66\left(\mathrm{CH}_{2}\right.$ linker $), 31.33\left(\mathrm{CH}_{3}\right), 25.48\left(\mathrm{CH}_{2 \mathrm{COD}}\right)$. Electrospray MS, cone $35 \mathrm{~V}, \mathrm{~m} / z$ (fragment): $519\left[\mathrm{M}^{+}\right]$. Anal. Calcd for $\mathrm{C}_{20} \mathrm{H}_{30} \mathrm{~F}_{6} \mathrm{IrN}_{4} \mathrm{P}$ (663.66): C, 36.20; H, 4.56; N, 8.44. Found: C, 36.14; H, 4.50; N, 8.44.

Synthesis of Tetramethylenebis( $N$ - $n$-butylimidazol-2-ylidene)(cyclooctadiene)iridium(I) Hexafluorophosphate, 8b. Transmetalation was carried out at room temperature in dichloromethane with tetramethylenebis $(N$ - $n$-butylimidazolium) dibromide (138 mg, 0.30 $\mathrm{mmol}), \mathrm{Ag}_{2} \mathrm{O}$ (172 mg, $\left.0.74 \mathrm{mmol}\right)$, and [(COD) $\left.\mathrm{IrCl}\right]_{2}(100 \mathrm{mg}$, $0.15 \mathrm{mmol}$ ). Column chromatography involved elution with $\mathrm{CH}_{2-}$ $\mathrm{Cl}_{2}$ /acetone (1:1), and $\mathrm{KPF}_{6}$ separated compound $\mathbf{8 b}$ as an orange band. Compound $\mathbf{8 b}$ was recrystallized from $\mathrm{CH}_{2} \mathrm{Cl}_{2} / \mathrm{Et}_{2} \mathrm{O}$ solution as an orange crystalline solid (yield $65 \%) .{ }^{1} \mathrm{H} \mathrm{NMR}\left(\mathrm{CDCl}_{3}, 300\right.$ $\mathrm{MHz}): \delta 7.16\left(\mathrm{~d}, 2 \mathrm{H}, \mathrm{CH}_{\text {imid }}\right), 7.04\left(\mathrm{~d}, 2 \mathrm{H}, \mathrm{CH}_{\text {imid }}\right), 4.82-4.99(\mathrm{q}$, $2 \mathrm{H}, \mathrm{CH}_{2}$ linker $), 4.50-4.41\left(\mathrm{~m}, 2 \mathrm{H}, \mathrm{CH}_{2}(n-\mathrm{Bu})\right), 4.24-4.20$ (m, $2 \mathrm{H}$, $\mathrm{CH}_{2}$ linker $), 4.10-3.92\left(\mathrm{~m}, 2 \mathrm{H}, \mathrm{CH}_{2}(n-\mathrm{Bu})\right), 3.79-3.82(\mathrm{~m}, 4 \mathrm{H}$, $\left.\mathrm{CH}_{\mathrm{COD}}\right), 2.38-2.16\left(\mathrm{~m}, 2 \mathrm{H}, \mathrm{CH}_{2}(n-\mathrm{Bu}), 2.1-1.4(\mathrm{~m}, 16 \mathrm{H} ; 8 \mathrm{H}\right.$, $\mathrm{CH}_{2} \mathrm{COD} ; 4 \mathrm{H}, \mathrm{CH}_{2}$ linker; $\left.4 \mathrm{H}, \mathrm{CH}_{2}(n-\mathrm{Bu})\right), 1.01\left(\mathrm{t}, 6 \mathrm{H}, \mathrm{CH}_{3}\right) .{ }^{13} \mathrm{C}$ NMR $\left(\mathrm{CDCl}_{3}, 300 \mathrm{MHz}\right): \delta 176.35(\mathrm{C}-\mathrm{Ir}), 122.12,120.95$ $\left(\mathrm{CH}_{\text {imid }}\right), 76.71,75.24\left(\mathrm{CH}_{\mathrm{COD}}\right), 50.66\left(\mathrm{NCH}_{2}\right.$ linker $), 46.18\left(\mathrm{NCH}_{2}-\right.$ $(n-\mathrm{Bu})), 32.98\left(\mathrm{CH}_{2}(n-\mathrm{Bu})\right), 31.61,31.57\left(\mathrm{CH}_{2 \mathrm{COD}}\right), 25.88\left(\mathrm{CH}_{2}\right.$ linker $), 20.43\left(\mathrm{CH}_{2}(n-\mathrm{Bu})\right), 13.95\left(\mathrm{CH}_{3}\right)$. Electrospray MS, cone 35 $\mathrm{V}, \mathrm{m} / \mathrm{z}$ (fragment): $603.4\left[\mathrm{M}^{+}\right]$. Anal. Calcd for $\mathrm{C}_{26} \mathrm{H}_{42} \mathrm{~F}_{6} \mathrm{IrN}_{4} \mathrm{P}$ (747.82): C, 41.76; H, 5.66; N, 7.49. Found: C, 41.70; H, 5.69; N, 7.45 .

Synthesis of the Dimeric Ir(III) Dihydride 9a. To a solution of complex 7a (100 mg, $0.15 \mathrm{mmol})$ in dichloromethane was added $\mathrm{HCl}$ (4 $\mathrm{M}$ solution in 1,4-dioxane, $10.7 \mu \mathrm{L}, 0.30 \mathrm{mmol}$ ). The solution turned immediately from orange to pale yellow. The desired product was obtained as a pale yellow solid by adding hexanes to the reaction mixture and separated by filtration (yield $80 \%$ ). ${ }^{1} \mathrm{H}$ NMR (acetone- $\left.d_{6}, 300 \mathrm{MHz}\right): \delta 7.12\left(\mathrm{~d}, 4 \mathrm{H}, \mathrm{CH}_{\text {imid }}\right), 6.82(\mathrm{~d}, 4 \mathrm{H}$, $\mathrm{CH}_{\text {imid }}$ ), 5.2-5.4 (m, 4H, $\mathrm{CH}_{2}$ linker $), 4.16$ (m, 4H, $\mathrm{CH}_{2}$ linker $), 3.74$ (s, 12H, $\left.\mathrm{CH}_{3}\right), 2.76$ (m, 4H, $\mathrm{CH}_{2}$ linker), -27.40 (Ir-hydride). Electrospray MS, cone $35 \mathrm{~V}, \mathrm{~m} / z$ (fragment): $901.1\left[\mathrm{M}^{+}\right]$. Anal. Calcd for $\mathrm{C}_{22} \mathrm{H}_{34} \mathrm{Cl}_{3} \mathrm{~F}_{6} \mathrm{Ir}_{2} \mathrm{~N}_{8} \mathrm{P}$ (1046.32): C, 25.25; H, 3.28; N, 10.71 . Found: C, 21.22; H, 3.30; N, 10.68.

Synthesis of the Dimeric Ir(III) Dihydride 9b. In a manner analogous that for $\mathbf{9 a}$, complex $\mathbf{9 b}$ was obtained by adding $\mathrm{HCl}$ (4 $\mathrm{M}$ solution in 1,4-dioxane, $10.7 \mu \mathrm{L}, 0.30 \mathrm{mmol}$ ) to a solution of complex $7 \mathbf{b}$ (100 mg, $0.14 \mathrm{mmol}$ ) in dichloromethane. The solution turned immediately to pale yellow. The desired product was obtained as a pale yellow solid by adding hexanes to the reaction mixture and separated by filtration (yield $80 \%) .{ }^{1} \mathrm{H}$ NMR $\left(\mathrm{CDCl}_{3}\right.$, $500 \mathrm{MHz}): \delta 7.19\left(\mathrm{~d}, 4 \mathrm{H}, \mathrm{CH}_{\text {imid }}\right), 7.10\left(\mathrm{~d}, 4 \mathrm{H}, \mathrm{CH}_{\mathrm{imid}}\right), 5.87(\mathrm{~m}$, $4 \mathrm{H}, \mathrm{CH}_{2}$ linker $), 5.5$ ( $\mathrm{m}, 2 \mathrm{H}, \mathrm{CH}_{2}$ linker $), 5.6\left(\mathrm{~m}, 2 \mathrm{H}, \mathrm{CH}_{2}\right.$ linker $), 4.37$ (m, 2H, $\mathrm{CH}_{2}$ linker) $)$ 4.17-4.16 (m, 8H, $\left.\mathrm{CH}_{2}(\mathrm{n}-\mathrm{Bu})\right), 4.10(\mathrm{~m}, 2 \mathrm{H}$, $\mathrm{CH}_{2}$ linker), 3.96-3.94 (m, 8H, $\left.\mathrm{CH}_{2}(n-\mathrm{Bu})\right), 1.36\left(\mathrm{~m}, 12 \mathrm{H}, \mathrm{CH}_{3}(n-\right.$ $\mathrm{Bu})$ ), 0.87-1.12 (m, 12H, $\left.\mathrm{CH}_{3}(n-\mathrm{Bu})\right),-27.71$ (Ir-hydride). Electrospray MS, cone $35 \mathrm{~V}, \mathrm{~m} / \mathrm{z}$ (fragment): $1069.1\left[\mathrm{M}^{+}\right]$. Anal. Calcd for $\mathrm{C}_{34} \mathrm{H}_{58} \mathrm{Cl}_{3} \mathrm{~F}_{6} \mathrm{Ir}_{2} \mathrm{~N}_{8} \mathrm{P}$ (1214.64): C, 33.62; H, 4.81; N, 9.23 Found: C, 33.65; H, 4.84; N, 9.27.

X-ray Diffraction Studies. Single crystals of 2Ir, 7b, 8a, and 9a were mounted on a glass fiber in a random orientation. Crystal data are summarized in Table 5. Data collection was performed at room temperature on a Siemens Smart CCD diffractometer using graphite-monochromated Mo $\mathrm{K} \alpha$ radiation $(\lambda=0.71073 \AA)$ with a nominal crystal to detector distance of $4.0 \mathrm{~cm}$. Space group assignment was based on systematic absences, E statistics, and 
Table 5. Crystallographic Data

\begin{tabular}{|c|c|c|c|c|}
\hline & $7 \mathbf{b}$ & $9 \mathbf{a}$ & $2 \mathrm{Ir}$ & $\mathbf{8 a}$ \\
\hline empirical formula & $\mathrm{C}_{25} \mathrm{H}_{37} \mathrm{~F}_{6} \mathrm{~N}_{4} \mathrm{PIr}$ & $\mathrm{C}_{22} \mathrm{H}_{34} \mathrm{Cl}_{3} \mathrm{~F}_{6} \mathrm{Ir}_{2} \mathrm{~N}_{8} \mathrm{O}_{0.5} \mathrm{P}$ & $\mathrm{C}_{17} \mathrm{H}_{25} \mathrm{ClF}_{6} \mathrm{IrN}_{4} \mathrm{P}$ & $\mathrm{C}_{20} \mathrm{H}_{30} \mathrm{~F}_{6} \mathrm{IrN}_{4} \mathrm{P}$ \\
\hline fw & 730.76 & 1054.29 & 658.03 & 663.65 \\
\hline wavelength $(\AA)$ & 0.71073 & 0.71073 & 0.71073 & 0.71073 \\
\hline crystal system & triclinic & monoclinic & monoclinic & monoclinic \\
\hline space group & $P \overline{1}$ & $P 2(1) / n$ & $P 2(1) / c$ & $P 2(1)$ \\
\hline$a(\AA)$ & $8.7176(13)$ & $13.4804(8)$ & $14.0793(6)$ & $12.0534(9)$ \\
\hline$b(\AA)$ & $11.7660(18)$ & $18.1685(11)$ & $11.4229(5)$ & $14.2223(10)$ \\
\hline$c(\AA)$ & 17.981(3) & $16.8361(11)$ & $14.1805(6)$ & $13.8876(10)$ \\
\hline$\alpha(\mathrm{deg})$ & $76.296(3)$ & 90.00 & 90.00 & 90.00 \\
\hline$\beta(\mathrm{deg})$ & $80.230(4)$ & $107.8910(10)$ & $109.3720(10)$ & $90.104(2)$ \\
\hline$\gamma(\mathrm{deg})$ & $70.657(3)$ & 90.00 & 90.00 & 90.00 \\
\hline$V(\AA)^{3}$ & $1682.3(4)$ & $3924.1(4)$ & $2151.48(16)$ & $2380.7(3)$ \\
\hline$Z$ & 2 & 4 & 4 & 4 \\
\hline density(calcd) $\left(\mathrm{Mg} / \mathrm{m}^{3}\right)$ & 1.443 & 1.785 & 2.032 & 1.852 \\
\hline abs coeff $\left(\mathrm{mm}^{-1}\right)$ & 4.067 & 7.074 & 6.467 & 5.737 \\
\hline no. of reflns collected & 13942 & 21954 & 17045 & 19488 \\
\hline goodness-of-fit on $F^{2}$ & 0.952 & 0.997 & 1.016 & 0.987 \\
\hline final $R$ indices & $\mathrm{R} 1=0.0759$ & $\mathrm{R} 1=0.0704$ & $\mathrm{R} 1=0.0337$ & $\mathrm{R} 1=0.0384$ \\
\hline$[I>2 \sigma(I)]$ & $w R 2=0.1861$ & $w R 2=0.1680$ & $\mathrm{wR} 2=0.0816$ & $\mathrm{wR} 2=0.0772$ \\
\hline
\end{tabular}

successful refinement of the structures. The structure was solved by direct methods with the aid of successive difference Fourier maps and was refined using the SHELXTL 5.1 software package. ${ }^{23}$ All non-hydrogen atoms were refined anisotropically. Hydrogen atoms were assigned to ideal positions and refined using a riding model. In the case of compound $\mathbf{2} \mathbf{I r}$, the high quality and extended range of the diffraction data allows location of the hydride ligand, in difference Fourier maps; it was introduced in the refinement as a free isotropic atom. Details of the data collection, cell dimensions, and structure refinement are given in Table 5. The diffraction frames were integrated using the SAINT package. ${ }^{24}$

Electrospray Mass Spectrometry. Electrospray mass spectra (ESI-MS) were recorded on a Micromass Quatro LC instrument using $\mathrm{CH}_{3} \mathrm{OH}$ as the mobile phase solvent. Nitrogen was employed as drying and nebilizing gas. Isotope experimental patterns were compared with theoretical patterns obtained using the Masslynx 3.5 program. In all cases there was good agreement between the experimental and calculated isotopic mass distributions.

Computational Details. Full geometry optimizations were carried out with the use of the B3LYP ${ }^{25}$ density functional level of theory combined with the LANL2DZ ${ }^{26}$ basis set and related pseudopotential on iridium. A 6-31G(d) basis set was employed for all the nitrogen atoms and for the carbon atoms directly linked to the metal center, while a nonpolarized 6-31G basis set was the choice for the other carbon atoms and the hydrogen atoms, apart from the hydridic hydrogen added to the metal, for which a 6-31G$(d, p)$ basis was preferred. For the optimized geometries, harmonic vibrational frequencies were calculated at the B3LYP level of theory. All transition structures possessed one and only one

(23) Sheldrick, G. M. SHELXTL, version 6.1; Bruker AXS, Inc.: Madison, WI, 2000

(24) SAINT, Bruker Analytical X-ray System, version 5.0; Bruker AXS, Inc.: Madison, WI, 1998.

(25) (a) Becke, A. D. J. Chem. Phvs. 1993, 98, 5648. (b) Stephens, P. J.; Devlin, F. J.; Chabalowski, C. F.; Frisch, M. J. J. Phvs. Chem. 1994, 98,11623 .

(26) Hay, P. J.; Wadt, W. R. J. Chem. Phvs. 1985, 82, 270. imaginary frequency. Solvent acetonitrile was introduced in the calculations by single-point electronic energy calculations on the DFT-optimized geometries, using the Polarizable Continuum Model approach, within the UA0 topological model (PCM/UA0). ${ }^{27}$ All calculations were performed with the Gaussian $03^{28}$ package.

Acknowledgment. We gratefully acknowledge financial support from the MEC of Spain (projects CTQ2005-05187 and CTQ2005-09000-C02-01) and Bancaixa (P1.1B2004-07). A.L. thanks the Generalitat of Catalunya for a Distinció per a la Promoció de la Recerca Universitaria. A.R. acknowledges the European Commission Program AQUACHEM (MRTN-CT2003-503864).

Supporting Information Available: X-ray crystallographic data in CIF format. This material is available free of charge via the Internet at http://pubs.acs.org.

OM051004L

(27) Cossi, M.; Barone, V.; Cammi, R.; Tomasi, J. Chem. Phvs. Lett. 1996, $255,327$.

(28) Frisch, M. J.; Trucks, G. W.; Schlegel, H. B.; Scuseria, G. E.; Robb, M. A.; Cheeseman, J. R.; Montgomery, J. A., Jr.; Vreven, T.; Kudin, K. N.; Burant, J. C.; Millam, J. M.; Iyengar, S. S.; Tomasi, J.; Barone, V.; Mennucci, B.; Cossi, M.; Scalmani, G.; Rega, N.; Petersson, G. A.; Nakatsuji, H.; Hada, M.; Ehara, M.; Toyota, K.; Fukuda, R.; Hasegawa, J.; Ishida, M.; Nakajima, T.; Honda, Y.; Kitao, O.; Nakai, H.; Klene, M.; Li, X.; Knox, J. E.; Hratchian, H. P.; Cross, J. B.; Bakken, V.; Adamo, C.; Jaramillo, J.; Gomperts, R.; Stratmann, R. E.; Yazyev, O.; Austin, A. J.; Cammi, R.; Pomelli, C.; Ochterski, J. W.; Ayala, P. Y.; Morokuma, K.; Voth, G. A.; Salvador, P.; Dannenberg, J. J.; Zakrzewski, V. G.; Dapprich, S.; Daniels, A. D.; Strain, M. C.; Farkas, O.; Malick, D. K.; Rabuck, A. D.; Raghavachari, K.; Foresman, J. B.; Ortiz, J. V.; Cui, Q.; Baboul, A. G.; Clifford, S.; Cioslowski, J.; Stefanov, B. B.; Liu, G.; Liashenko, A.; Piskorz, P.; Komaromi, I.; Martin, R. L.; Fox, D. J.; Keith, T.; Al-Laham, M. A.; Peng, C. Y.; Nanayakkara, A.; Challacombe, M.; Gill, P. M. W.; Johnson, B.; Chen, W.; Wong, M. W.; Gonzalez, C.; and Pople, J. A. Gaussian 03, Revision C.02; Gaussian, Inc.: Wallingford, CT, 2004. 